\title{
GMR
}

\section{Molecular phylogeny and biotechnological potential of bacterial endophytes associated with Malpighia emarginata}

V. Specian ${ }^{1}$, A.T. Costa ${ }^{1}$, A.C. Felber ${ }^{1}$, J.C. Polonio ${ }^{1}$, J.L. Azevedo ${ }^{2}$ and J.A. Pamphile ${ }^{1}$

${ }^{1}$ Departamento de Biotecnologia, Genética e Biologia Celular, Universidade Estadual de Maringá, Maringá, PR, Brasil

${ }^{2}$ Departamento de Genética, Escola Superior de Agricultura “Luiz de Queiroz", Universidade de São Paulo, Piracicaba, SP, Brasil

Corresponding author: J.A. Pamphile

E-mail: prof.pamphile@gmail.com

Genet. Mol. Res. 15 (2): gmr.15027777

Received October 5, 2015

Accepted December 3, 2015

Published April 26, 2016

DOI http://dx.doi.org/10.4238/gmr.15027777

\begin{abstract}
Acerola (Malpighia emarginata) is a shrub native to tropical and subtropical climates, which has great commercial interest due to the high vitamin $\mathrm{C}$ content of its fruit. However, there are no reports of the endophytic community of this plant species. The aim of this study was to verify the genetic diversity of the leaf endophytic bacterial community of two varieties (Olivier \& Waldy Cati 30) of acerola, and to evaluate their biotechnological ability by assessing their in vitro control of pathogenic fungi and the enzymatic production of cellulase, xylanase, amylase, pectinase, protease, lipase, esterase, and chitinase. In total, 157 endophytic bacteria were isolated from the leaves of two varieties of the plant at $28^{\circ}$ and $37^{\circ} \mathrm{C}$. Phylogenetic analysis confirmed the molecular identification of 58 bacteria, $39.65 \%$ of which were identified at the species level. For the first time, the genus Aureimonas was highlighted as an endophytic bacterium. Furthermore, $12.82 \%$ of the isolates inhibited the growth of all phytopathogens evaluated and
\end{abstract}


at least one of the above-mentioned enzymes was produced by $64.70 \%$ of the endophytes, demonstrating that $M$. emarginata isolates have potential use in biotechnological studies.

Key words: Endophytes; Acerola; Phylogenetic analysis; Antagonistic activity; Enzymes

\section{INTRODUCTION}

Malpighia emarginata D.C., also referred to as West Indian cherry, Caribbean cherry, Barbados cherry, and popularly termed acerola in Brazil, is a wild plant that originated in southern Mexico and in the northern region of South America (Carrington and King, 2002). This species was introduced to Brazil about 65 years ago, and its production is concentrated mainly in the northeastern, southeastern, and southern regions of the country (Santos et al., 2012). Brazil is considered the biggest producer, consumer, and exporter of acerola in the world (Cavichioli et al., 2014). This fruit is now used widely for preparing juices and for general consumption because of its high levels of vitamin C (Cavichioli et al., 2014).

Endophytes are microorganisms that inhabit the interior of plant tissues during all or part of their life cycle, without causing any visible symptoms (Azevedo et al., 2000; Kusari et al., 2012). All plants harbor a diverse community of endophytic bacteria, which live in symbiosis with plants, passing through epiphytic and endophytic colonization. These bacteria may be isolated from the vegetal tissue after surface disinfection (Lacava and Azevedo, 2013).

These bacteria stimulate plant growth, yield, can act as biological control agents, and produce a variety of natural products that have potential use in medicine, agriculture, and industry. They may also remove contaminants from soil by promoting phytoremediation and may influence soil fertility via phosphate solubilization and nitrogen fixation (Anand et al., 2014).

Molecular approaches based on PCR amplification and sequencing of the 16S rRNA gene are important tools for use in taxonomy and bacterial identification, and are used to identify new pathogens and to define complex microbial communities (Schlaberg et al., 2012). The function of the 16S rRNA gene has not changed over the course of evolution, suggesting that random-sequence alterations are a relatively accurate measure of time.

As they colonize a similar ecological niche as phytopathogens, endophytic bacteria are suitable for use as biocontrol agents. Various reports have shown that endophytic microorganisms have the ability to control several plant pathogens (Chebotar et al., 2015). The "biocontrol activity" of microorganisms is defined as their ability to reduce populations of target species of antagonist-organisms through a variety of ecological mechanisms, including pathogenesis, competition within the ecological niche, and the production of compounds that inhibit their growth and development (Chebotar et al., 2015).

An efficient antagonist against several fungal pathogens is Bacillus subtilis, due to its production of antifungal compounds, antibiotics, and proteases, causing this species to be extensively used in agricultural systems (Soria et al., 2012). The inhibitory effect of live bacteria and their thermostable metabolites on the in vitro growth of Fusarium circinatum, the phytopathogen that induces cancer of the pine (Pinus taeda L.), were demonstrated by four endophyte isolates of $B$. subtilis and one isolate of Burkholderia sp. In this study, all bacteria displayed an antagonist effect on pathogen growth and the thermostable metabolites inhibited 
fungal growth by over $50 \%$, demonstrating that endophytic bacteria constitute an alternative method of F. circinatum control (Soria et al., 2012; Chebotar et al., 2015).

Microbial enzymes are of great importance because they act as biocatalysts in several industries, including biotechnology, agricultural, and pharmaceutical industries. Bacteria have been used in the production of enzymes for years, and microbial cultivated enzymes have replaced animal or plant enzymes (Duza and Mastan, 2013). Bacterial hydrolytic enzymes like cellulases and pectinases are also used by endophytic bacteria to penetrate plant tissues (Gujral et al., 2013). Due the high production capability, low cost, and susceptibility to genetic manipulation, enzymatic production processes have generated much biotechnological interest (Castro et al., 2014).

Prompted by the great potential of endophyte microorganisms and the lack of information on endophytes isolated from acerola leaves, the aim of this study was to verify the genetic diversity of the leaf bacterial endophyte community of two varieties of $M$. emarginata (Olivier \& Waldy Cati 30), and to evaluate their biotechnological ability in relation to the production of enzymes and the in vitro control of phytopathogenic fungi.

\section{MATERIAL AND METHODS}

\section{Leaf sampling}

Healthy and undamaged adult leaves were randomly collected from two varieties (Olivier \& Waldy Cati 30) of M. emarginata on the 170-ha Experimental Farm of the Universidade Estadual de Maringá, Iguatemi, in the northwestern region of the State of Paraná, Brazil, $23^{\circ} 25^{\prime} \mathrm{S}$ and $51^{\circ} 57^{\prime} \mathrm{W}$, altitude $550 \mathrm{~m}$. Leaves were collected under a mean temperature of $22.3^{\circ} \mathrm{C}$ and relative air humidity $60 \%$, with mean rainfall index of $29.7 \mathrm{~mm}$. Data on temperature and rainfall were retrieved from http://www.inmet.gov.br (National Institute of Meteorology), station A835. The leaf material was processed in the Laboratory of Microbial Biotechnology of the State University of Maringa, Maringá, Paraná, Brazil (BIOMIC-UEM).

\section{Isolation and maintenance of endophytic bacteria}

Leaves were washed in running water to remove residue, cleansed with $0.01 \%$ Tween 80 aqueous solution (Synth), and washed twice in autoclaved distilled water. Surface disinfection was undertaken under running water with immersion in $3 \%$ sodium hypochlorite (active chlorine) for $4 \mathrm{~min}$. The efficiency of the method was evaluated by spreading $100 \mu \mathrm{L}$ of the water used on Petri dishes containing LB culture medium $(10 \mathrm{~g} / \mathrm{L}$ tryptone, $5 \mathrm{~g} / \mathrm{L}$ yeast extract, $10 \mathrm{~g} / \mathrm{L} \mathrm{NaCl}$, $15 \mathrm{~g} / \mathrm{L}$ agar, in $1 \mathrm{~L}$ distilled water; $\mathrm{pH} 7.0)$, supplemented with fungicide Benomyl (50 $\mu \mathrm{g} / \mathrm{mL}$ in absolute ethanol). All procedures were performed separately for each variety.

Five leaf fragments $\left(5 \mathrm{~mm}^{2}\right)$ were placed on each Petri dish containing LB medium supplemented by Benomyl, and incubated at $28^{\circ}$ and $37^{\circ} \mathrm{C}$ for $3-4$ days until bacterial growth was evident on most fragments. Frequency of isolation (FI) was determined by FI $=$ (number of fragments colonized bacteria/total number of leaf fragment) x 100 .

Isolates were transferred to plates containing LB medium and further incubated at $28^{\circ}$ and $37^{\circ} \mathrm{C}$, complying with the isolation temperature. After 2-5 days, depending on growth 
requirements required for each isolate, bacteria were purified using the streaking technique to obtain pure colonies. The codes used to distinguish the origin of isolates and temperatures of isolation were according to the Table 1 .

Table 1. Codification used to distinguish the origin of endophytes (plant variety) and temperature used to growth of the bacteria.

\begin{tabular}{l|l|c|c}
\hline Codes & Description & Example 1 & Example 2 \\
\hline First letter & Abbreviation of the group. & $\mathrm{G}$ & $\mathrm{G}$ \\
\hline First number & Number attributed to group based on the morphological characteristics of the isolates. & 1 & 2 \\
\hline Second letter & The variety from where the endophyte was retrieved, O (Olivier) and W (Waldy Cati 30). & $\mathrm{O}$ & W \\
\hline Second number & Number given to the isolate within the group. & 33 & 2 \\
\hline Letter between brackets & Temperature of isolation, A $\left(37^{\circ} \mathrm{C}\right)$ and B $\left(28^{\circ} \mathrm{C}\right)$. & (A) & (B) \\
\hline Results & G1O33 (A) & G2W2 (B) \\
\hline
\end{tabular}

Previous assessments showed that bacterial isolates grew better in TSA culture medium (Tryptone Soy Agar, HIMEDIA) (data not shown). All isolates were kept in TSA and cultures of pure colonies were maintained at $28^{\circ}$ and $37^{\circ} \mathrm{C}$ for 2 days prior to the start of each experiment. Isolates were preserved by freezing in $30 \%$ glycerol and were stored at $-20^{\circ} \mathrm{C}$.

\section{Identification of endophyte isolates}

Bacterial DNA was extracted following the method described by Nogueira et al. (2004), with modifications. Endophytic bacteria were grown in $5 \mathrm{~mL} \mathrm{LB}$ broth for $24 \mathrm{~h}$ at $28^{\circ} \mathrm{C}$. Next, $400 \mu \mathrm{L}$ of the suspension was transferred to microtubes, to which $400 \mu \mathrm{L}$ of saturated phenol solution was added. The mixture was stirred $\left(\right.$ Vorte $\left.^{\circledR}\right)$ and centrifuged at $16,000 \mathrm{~g}$ for $5 \mathrm{~min}$. The supernatant (water phase) was transferred to another microtube and the phenolic stage replicated. After centrifugation, the supernatant was transferred to another microtube containing $400 \mu \mathrm{L}$ chloroform. The microtube was vortexed and centrifuged for 5 $\min$ at $16,128 \mathrm{~g}$. The water layer was transferred to another microtube to which $1 \mathrm{~mL}$ ethanol was added. The DNA extraction was completed when the microtube was centrifuged for $3 \mathrm{~min}$ at $16,128 \mathrm{~g}$, and a DNA pellet was formed. The ethanol was disposed of and the tubes were exposed to $37^{\circ} \mathrm{C}$ for $30 \mathrm{~min}$ to allow any ethanol to evaporate. The pellet was then eluted in $15 \mu \mathrm{L}$ autoclaved ultrapure water.

The 16S region of rDNA was amplified following the method described by Procópio et al. (2009), with modifications. The PCR was performed in a final volume of $50 \mu \mathrm{L}$ containing $5 \mu \mathrm{L}$ buffer (200 mM Tris-HCl, pH 8.4, $500 \mathrm{mM} \mathrm{KCl}), 5 \mu \mathrm{L}$ dNTPs $(2.5 \mathrm{mM}), 3 \mu \mathrm{L}$ of each primer (Invitrogen pmol/ $\mu \mathrm{L} \mathrm{10}{ }^{-1}$ ) (R1378: 5'-CGGTGTGTACAAGGCCCGGAACG-3' and PO27F: 5'-GAGAGTTTGATCCTGGCTCAG-3'), $0.4 \mu \mathrm{L}$ Taq DNA polymerase $(5 \mathrm{U} / \mu \mathrm{L})$, $3.75 \mu \mathrm{L} \mathrm{MgCl}_{2}(50 \mathrm{mM}), 27.85 \mu \mathrm{L}$ ultrapure water, and $2 \mu \mathrm{L}$ sample DNA $(10-20 \mathrm{ng} / \mu \mathrm{L})$. PCR conditions comprised initial denaturation at $94^{\circ} \mathrm{C}$ for $4 \mathrm{~min}$, followed by 25 cycles: denaturation at $94^{\circ} \mathrm{C}$ for $30 \mathrm{~s}$; annealing at $63^{\circ} \mathrm{C}$ for $1 \mathrm{~min}$; extension at $72^{\circ} \mathrm{C}$ for $1 \mathrm{~min}$, and a final extension at $72^{\circ} \mathrm{C}$ for $7 \mathrm{~min}$. Amplification products were purified with two enzymes, shrimp alkaline phosphatase (SAP) and exonuclease I (EXO). Reactions were performed using $8 \mu \mathrm{L}$ PCR product, $0.5 \mu \mathrm{L} \mathrm{EXO}(10 \mathrm{U} / \mu \mathrm{L})$, and $1 \mu \mathrm{L} \mathrm{SAP}(1 \mathrm{U} / \mu \mathrm{L})$, and incubated in a thermocycler for $1 \mathrm{~h}$ at $37^{\circ} \mathrm{C}$, followed by $15 \mathrm{~min}$ at $80^{\circ} \mathrm{C}$, and were conserved at $4^{\circ} \mathrm{C}$. Samples were sequenced by ACTGene Análises Moleculares Ltd. (Ludwigbiotec). 
Sequences were then analyzed and edited. Isolates were identified from the percentage identity and sequence coverage compared to those deposited in GenBank (http://www.ncbi. nlm.nih.gov) with BLASTn.

A similarity dendrogram was generated for phylogenetic analyses using the sequences obtained by sequencing and those deposited in GenBank. Sequences were paired by Clustal W and with the dendrogram produced by MEGA 6 (Tamura et al., 2013), by the neighbor-joining method, p-distance for nucleotides with the pairwise gap deletion and bootstrap with 10,000 replications.

All rDNA 16S gene sequences in the current study were analyzed with Decipher to verify the presence of chimeras. After identification, sequences were compared with those belonging to the type strain from the LPSN database (http://www.bacterio.net). Sequences were compared using BLASTn with the Entrez Query option (with the addition of the accession No. of type strain sequences). All rDNA 16S gene sequences in the current study were deposited in the NCBI GenBank under the accession Nos. KR005461 to KR005518 (Table 2).

\begin{tabular}{|c|c|c|c|c|c|c|c|}
\hline \multirow[t]{2}{*}{ Endophyte strain (GenBank) } & \multirow[t]{2}{*}{ Plant variety } & \multirow[t]{2}{*}{ Isolation temp. } & \multicolumn{2}{|l|}{ BLAST (GenBank)* } & \multicolumn{2}{|c|}{ Type strain sequence*** } & \multirow[t]{2}{*}{ Taxonomic identification $* * *$} \\
\hline & & & Accession No. with highest identity & Identity (\%) & Accession No. & Identity (\%) & \\
\hline G1O17 (A) (KR005461) & Olivier & $37^{\circ} \mathrm{C}$ & KM042087.1 & 100 & - & - & Enterobacter $\mathrm{sp}$ \\
\hline G1O33 (A) (KR005462) & Olivier & $37^{\circ} \mathrm{C}$ & JN585689.1 & 96 & - & - & Staphylococcus sp \\
\hline G1O38 (A) (KR005463) & Olivier & $37^{\circ} \mathrm{C}$ & KM250109.1 & 98 & - & - & Staphylococcus sp \\
\hline G2O23 (A) (KR005464) & Olivier & $37^{\circ} \mathrm{C}$ & KM203879.1 & 99 & - & - & Staphylococcus sp \\
\hline G2O39 (A) (KR005465) & Olivier & $37^{\circ} \mathrm{C}$ & KM083802.1 & 99 & - & - & Staphylococcus sp \\
\hline G2O43 (A) (KR005466) & Olivier & $37^{\circ} \mathrm{C}$ & KM015449.1 & 97 & AF094748 & $97 \%$ & Pseudomonas stutzeri \\
\hline G3O37 (A) (KR005467) & Olivier & $37^{\circ} \mathrm{C}$ & KF017561.1 & 100 & - & - & Bacillus sp \\
\hline G3029 (A) (KR005468) & Olivier & $37^{\circ} \mathrm{C}$ & KM083802.1 & 100 & - & - & Staphylococcus sp \\
\hline G5O14 (A) (KR005469) & Olivier & $37^{\circ} \mathrm{C}$ & KM042087.1 & 100 & - & - & Enterobacter $\mathrm{sp}$ \\
\hline G5O25 (A) (KR005470) & Olivier & $37^{\circ} \mathrm{C}$ & FJ842658.1 & 100 & - & - & Bacillus $\mathrm{sp}$ \\
\hline G5O27 (A) (KR005471) & Olivier & $37^{\circ} \mathrm{C}$ & $\begin{array}{l}r 04200.1 \\
\text { EU071560.1 }\end{array}$ & 99 & - & - & $\begin{array}{l}\text { Dacillus sp } \\
\text { Bp }\end{array}$ \\
\hline G5O47 (A) (KR005472) & Olivier & $37^{\circ} \mathrm{C}$ & KM052592.1 & 100 & $\begin{array}{l}\mathrm{CP} 000002.3 \\
\end{array}$ & $99 \%$ & Bacillus licheniformis \\
\hline G5O48 (A) (KR005473) & Olivier & $37^{\circ} \mathrm{C}$ & KM052592.1 & 99 & CP000002.3 & $99 \%$ & Bacillus licheniformis \\
\hline G5O49 (A) (KR005474) & Olivier & $37^{\circ} \mathrm{C}$ & JN812081.1 & 99 & СР000002.3 & $99 \%$ & Bacillus licheniformis \\
\hline G8031 (A) (KR005475) & Olivier & $37^{\circ} \mathrm{C}$ & KM052592.1 & 96 & CP000002.3 & $96 \%$ & Bacillus licheniformis \\
\hline G8O36 (A) (KR005476) & Olivier & $37^{\circ} \mathrm{C}$ & KM093730.1 & 100 & - & - & Bacillus sp \\
\hline G8037 (A) (KR005477) & Olivier & $37^{\circ} \mathrm{C}$ & KM203879.1 & 100 & - & - & Staphylococcus sp \\
\hline G8O43 (A) (KR005478) & Olivier & $37^{\circ} \mathrm{C}$ & KF017550.1 & 100 & - & - & Bacillus sp \\
\hline G8O50 (A) (KR005479) & Olivier & $37^{\circ} \mathrm{C}$ & KM016934.1 & 100 & - & - & Bacillus sp \\
\hline G1W28 (A) (KR005480) & Waldy Cati 30 & $37^{\circ} \mathrm{C}$ & KM093730.1 & 99 & - & - & Bacillus sp \\
\hline $\begin{array}{l}\text { G4W14 (A) (KR005481) } \\
\end{array}$ & Waldy Cati 30 & $37^{\circ} \mathrm{C}$ & KM042089.1 & 100 & - & - & Enterobacter $\mathrm{sp}$ \\
\hline G1O1 (B) (KR005482) & Olivier & $28^{\circ} \mathrm{C}$ & HG810389.1 & 98 & Z93440.1 & $97 \%$ & Acinetobacter johnsonii \\
\hline G1O8 (B) (KR005483) & Olivier & $28^{\circ} \mathrm{C}$ & KJ995847.1 & 99 & Z93440.1 & $99 \%$ & Acinetobacter johnsonii \\
\hline G109 (B) (KR005484) & Olivier & $28^{\circ} \mathrm{C}$ & KJ.J03945.1 & 92 & D84020 & $90 \%$ & Pseudomonas putida \\
\hline G1O24 (B) (KR005485) & Olivier & $28^{\circ} \mathrm{C}$ & AM184286.1 & 95 & D84020 & $92 \%$ & Pseudomonas putida \\
\hline GIO32 (B) (KR005486) & Olivier & $28^{\circ} \mathrm{C}$ & KJ 803945.1 & 99 & D84020 & $96 \%$ & Pseudomonas putida \\
\hline G1O38 (B) (KR005487) & Olivier & $28^{\circ} \mathrm{C}$ & KM250110.1 & 100 & D16281 & $100 \%$ & Bacillus thurigiensis \\
\hline G1O39 (B) (KR005488) & Olivier & $28^{\circ} \mathrm{C}$ & KJ 880015.1 & 100 & Z93440.1 & $99 \%$ & Acinetobacter johnsonii \\
\hline G1O47 (B) (KR005489) & Olivier & $28^{\circ} \mathrm{C}$ & HG941660.1 & 100 & & - & Staphylococcus sp \\
\hline $\mathrm{G} 2 \mathrm{O} 26$ (B) (KR005490) & Olivier & $28^{\circ} \mathrm{C}$ & KJJ943979.1 & 99 & - & - & Bacillus sp \\
\hline G2O29 (B) (KR005491) & Olivier & $28^{\circ} \mathrm{C}$ & KM108311.1 & 100 & D16281 & $99 \%$ & Bacillus thurigiensis \\
\hline G2O34 (B) (KR005492) & Olivier & $28^{\circ} \mathrm{C}$ & KM250109.1 & 100 & - & - & Staphylococcus sp \\
\hline & Olivier & $28^{\circ} \mathrm{C}$ & HQ880685.1 & 85 & - & - & Bacillus $\mathrm{sp}$ \\
\hline G3O6 (B) (KR005494) & Olivier & $28^{\circ} \mathrm{C}$ & KJ 803945.1 & 100 & D84020 & $97 \%$ & Pseudomonas putida \\
\hline G3O14 (B) (KR005495) & Olivier & $28^{\circ} \mathrm{C}$ & KM042089.1 & 100 & & & Enterobacter $\mathrm{sp}$ \\
\hline G3O15 (B) (KR005496) & Olivier & $28^{\circ} \mathrm{C}$ & KM250110.1 & 100 & D16281 & $100 \%$ & Bacillus thurigiensis \\
\hline G3O25 (B) (KR005497) & Olivier & $28^{\circ} \mathrm{C}$ & KJ 3880015.1 & 100 & $\mathrm{Z} 93440.1$ & $99 \%$ & Acinetobacter johnsonii \\
\hline G3O46 (B) (KR005498) & Olivier & $28^{\circ} \mathrm{C}$ & $\begin{array}{l}\text { HM567114.1 } \\
\text { KM108311.1 }\end{array}$ & $\begin{array}{l}99 \\
99\end{array}$ & D16281 & $98 \%$ & Bacillus thurigiensis \\
\hline $\begin{array}{l}\text { G4O4 (B) (KR005499) } \\
\end{array}$ & Olivier & $28^{\circ} \mathrm{C}$ & KF018921.2 & 99 & & - & Bacillus sp \\
\hline G5O18 (B) (KR005500) & Olivier & $28^{\circ} \mathrm{C}$ & HE681737.1 & 98 & X77445 & $97 \%$ & Microbacterium testaceum \\
\hline G7O36 (B) (KR005501) & Olivier & $28^{\circ} \mathrm{C}$ & KF018921.2 & 100 & - & - & Bacillus sp \\
\hline G8O43 (B) (KR005502) & Olivier & $28^{\circ} \mathrm{C}$ & KF018921.2 & 100 & - & - & Bacillus $\mathrm{sp}$ \\
\hline G8O49 (B) (KR005503) & Olivier & $28^{\circ} \mathrm{C}$ & KM186185.1 & 100 & - & & Bacillus sp \\
\hline G8O51 (B) (KR005504) & Olivier & $28^{\circ} \mathrm{C}$ & $\begin{array}{l}\text { KF891394.1 } \\
\text { JQ660180.1 }\end{array}$ & $\begin{array}{l}89 \\
89\end{array}$ & $\mathrm{X} 82598$ & $88 \%$ & Cellulomonas hominis \\
\hline G1W1 (B) (KR005505) & Waldy Cati 30 & $28^{\circ} \mathrm{C}$ & KJ744023.1 & 99 & AJ536198 & $99 \%$ & Micrococcus luteus \\
\hline
\end{tabular}

*Percent identity based on the comparison of rDNA sequences of endophytic bacteria deposited in GenBank using BLAST. **Comparison of endophytic bacteria with bacteria from the LPSN database (List of Prokaryotic names with Standing in Nomenclature) (http://www.bacterio.net/) and compared with BLAST. ${ }^{* * *}$ Taxonomic identity of endophytic bacteria based on the following analyses: BLAST $(*)$, type strain sequences $(* *)$, and phytogenetic analysis. 


\section{Antagonistic activity of endophytic isolates against phytopathogenic fungi in vitro}

Isolates of endophytic bacteria from the leaf tissue of $M$. emarginata were used to perform an antagonism assay against seven phytopathogens (Table 3).

\begin{tabular}{|c|c|c|c|}
\hline Species & Disease & Host plant & Laboratory \\
\hline Glomerella sp (CNPUV 102) & Grape rottenness, anthracnose & Grapevine, acerola & EMBRAPA Grape and Wine of Bento Gonçalves - RS, Brazil \\
\hline Sclerotinia sclerotiorum & White Mold; white rottenness & Soy bean, sun flower, canola, peas, beans, potato & $\begin{array}{l}\text { Laboratory of Genetics of Microorganisms "João Lúcio de Azevedo" } \\
\text { ESALQ - USP, SP, Brazil }\end{array}$ \\
\hline Moniliophthora perniciosa & Witches' broom & Cocoa & $\begin{array}{l}\text { Laboratory of Genetics of Microorganisms "João Lúcio de Azevedo" } \\
\text { ESALQ - USP, SP, Brazil }\end{array}$ \\
\hline Fusarium solani & Red rottenness of the root & Soy bean & $\begin{array}{l}\text { Laboratory of Genetics of Microorganisms "João Lúcio de Azevedo" } \\
\text { ESALQ - USP, SP, Brazil }\end{array}$ \\
\hline Didymella bryoniae & Gummy stem blight & Watermelon, melon & $\begin{array}{l}\text { Laboratory of Genetics of Microorganisms "João Lúcio de Azevedo" } \\
\text { ESALQ - USP, SP, Brazil }\end{array}$ \\
\hline Alternaria sp (CNPUV 674) & Early blight; black spot & Acerola, mango, tomato, potato, eggplant & EMBRAPA Grape and Wine of Bento Gonçalves - RS, Brazil \\
\hline Fusarium oxysporum (ATCC 2163) & Fusariosis & Acerola & Institution André Tosello, Campinas, SP, Brazil \\
\hline
\end{tabular}

In vitro antagonism assays were conducted by dual culture to verify the capacity of the endophytes to inhibit phytopathogen growth. Fungi were previously grown on potato dextrose agar (PDA) culture medium at $28^{\circ} \mathrm{C}$ for 7 days. The 39 endophytic bacteria were grown in TSA medium at $28^{\circ} \mathrm{C}$ for $24 \mathrm{~h}$. After this period, each bacterium was striated along two edges of a Petri dish ( $1 \mathrm{~cm}$ from the margin) containing PDA. After $48 \mathrm{~h}$, each fungus (6-mm discs) was transferred to the center of the dish ( $3 \mathrm{~cm}$ from each bacterial striate). Two controls were used: in the first control, phytopathogens were inoculated in the middle of the Petri dish to assess their maximum growth; in the second control, 6-mm discs of the same phytopathogens were placed at the edges of the dishes equidistant at $4 \mathrm{~cm}$. Tests were performed in triplicate and all dishes were incubated at $28^{\circ} \mathrm{C}$ for 6 days. The capacity of isolates to inhibit pathogen fungi was determined by measuring the growth size (in $\mathrm{cm}$ ) of the pathogen in the experiment and in the controls.

\section{Evaluation of the enzymatic activity of endophytic isolates}

M. emarginata isolates were tested for their capacity to produce cellulase, xylanase, amylase, pectinase, protease, lipase, esterase, and chitinase in solid culture media. Thirtyfour strains of endophytic bacteria were grown in tryptone soy broth (TSB, HIMEDIA) liquid medium for $48 \mathrm{~h}$ at $28^{\circ} \mathrm{C}$. The bacteria were then stirred and eluted in $5 \mathrm{~mL} 1 \%$ saline solution to obtain a concentration of $10^{8}$ colony-forming units per milliliter (CFU/ $\mathrm{mL}$ ), equivalent to 0.5 on the McFarland scale. Next, $2 \mu \mathrm{L}$ of the culture was inoculated on Petri dishes containing minimal medium for bacteria, -M9 $200 \mathrm{~mL} / \mathrm{L}$ stock solution (64 $\left.\mathrm{g} / \mathrm{L} \mathrm{Na}_{2} \mathrm{HPO}_{4} .7 \mathrm{H}_{2} \mathrm{O} ; 15 \mathrm{~g} / \mathrm{L} \mathrm{KH}_{2} \mathrm{PO}_{4} ; 2.5 \mathrm{~g} / \mathrm{L} \mathrm{NaCl} ; 5 \mathrm{~g} / \mathrm{L} \mathrm{NH}_{4} \mathrm{Cl}\right) ; 2.0 \mathrm{~mL} / \mathrm{L} 1 \mathrm{M} \mathrm{MgSO}$; $10 \mathrm{~g} / \mathrm{L}$ carbon source; $0.1 \mathrm{~mL} / \mathrm{L} \mathrm{CaCl}_{2} 1 \mathrm{M} ; 15 \mathrm{~g} / \mathrm{L}$ agar, $\mathrm{pH} 7.2$, with the following carbon sources [amylase $0.5 \%$, yeast extract, and $1 \%$ soluble starch $(\mathrm{v} / \mathrm{v})]$ cellulase $[0.5 \%$ yeast extract and $1 \%$ carboxymethylcellulose $(\mathrm{v} / \mathrm{v})]$, pectinase $[0.5 \%$ yeast extract and $1 \%$ pectin $(\mathrm{v} / \mathrm{v}), \mathrm{pH} 8.0]$, xylanase $[0.5 \%$ yeast extract and $1 \%$ xylan $(\mathrm{v} / \mathrm{v})]$. To evaluate lipolithic and esterastic activity, lipase/esterase medium was used $(10 \mathrm{~g} / \mathrm{L}$ peptone; $5 \mathrm{~g} / \mathrm{L} \mathrm{NaCl} ; 0.1 \mathrm{~g} / \mathrm{L}$ $\mathrm{CaCl}_{2} \cdot \mathrm{H}_{2} \mathrm{O} ; 15 \mathrm{~g} / \mathrm{L}$ agar; $\mathrm{pH} 7.4$ ) with $1 \%(\mathrm{v} / \mathrm{v})$ Tween 20 for lipase and Tween 80 for esterase. To investigate proteolytic activity, protease medium was used $(5 \mathrm{~g} / \mathrm{L}$ tryptone; $2.5 \mathrm{~g} / \mathrm{L}$ yeast extract; $1.0 \mathrm{~g} / \mathrm{L}$ glucose; $2.5 \mathrm{~g} / \mathrm{L} \mathrm{NaCl} ; 15 \mathrm{~g} / \mathrm{L}$ agar; $\mathrm{pH} 7.0$ ); after autoclaving, 100 
$\mathrm{mL}$ skimmed milk was added per $900 \mathrm{~mL}$ medium. To detect enzymatic activity, the incubation period ranged from 24 to $168 \mathrm{~h}$ at $28^{\circ} \mathrm{C}$. To visualize the enzyme activities of cellulase, amylase, pectin, and protease, congo red dye, iodine tincture, $\mathrm{HCl} 5 \mathrm{~N}$, and acetic acid were used, respectively; revealers were not required for the others, since enzymatic production could be visualized as a bright halo around the colonies (Oliveira et al., 2006). Commercial enzymes were used as a positive control; these included protease (Aspergillus oryzae), porcine pancreatic $\alpha$-amylase, and pectinase (Aspergillus niger; Sigma). The negative control comprised $1 \%$ saline solution. Semi-quantitative enzymatic activity was evaluated by calculating the enzymatic index (EI) using the formula EI = halo diameter $(\mathrm{cm}) /$ diameter of the colony $(\mathrm{cm})$.

\section{Statistical analyses}

Experiments were randomized and statistically analyzed by analysis of variance (ANOVA); means were compared by the Scott-Knott test $(\mathrm{P}<0.05)$ using Sisvar 4.3 (Ferreira, 2011).

\section{RESULTS}

\section{Isolation and identification of endophytic bacteria}

A total of 250 leaf fragments were sampled for each variety of $M$. emarginata and for each temperature; a total of 157 bacterial isolates were subdivided as follows: Olivier variety $=53$ isolates $(\mathrm{FI}=21.2 \%)$ obtained at $28^{\circ} \mathrm{C}$; 50 isolates $(\mathrm{FI}=20 \%)$ at $37^{\circ} \mathrm{C}$; Waldy Cati variety 30 with 26 isolates $(\mathrm{FI}=10.4 \%)$ obtained at $28^{\circ} \mathrm{C}$ and 28 isolates $(\mathrm{FI}=11.2 \%)$ at $37^{\circ} \mathrm{C}$.

These 157 endophytic bacteria were isolated and purified by the streaking method and grouped in morphogroups according to the morphological characteristics of color, colony formation, viscosity, development, and growth on TSA. In the case of the Olivier variety, bacteria isolated at $28^{\circ} \mathrm{C}$ were placed in nine groups and those isolated at $37^{\circ} \mathrm{C}$ were placed in a further eight groups. For the Waldy Cati variety, 30 bacteria were isolated at $28^{\circ} \mathrm{C}$ and placed in six groups, and those isolated at $37^{\circ} \mathrm{C}$ were also grouped into six groups. In total, 63/157 bacteria were randomly selected and used for further analyses.

Sequencing analyses of $16 \mathrm{~S}$ rDNA led to the identification of 58 isolates distributed in nine genera: Bacillus (corresponding at $36.20 \%$ of the isolates), Staphylococcus (17.24\%), Enterobacter (12.06\%), Pseudomonas and Microbacterium (10.34\% each), and Acinetobacter (6.89\%). The genera Aureimonas, Cellulomonas, and Micrococcus were represented by a single endophyte. The endophyte sequences of $M$. emarginata shared $85-100 \%$ identity with those available in GenBank.

\section{Molecular phylogeny analysis of endophytic bacteria of $M$. emarginata based on rDNA sequencing}

The molecular phylogeny analysis divided the endophytic bacteria into 10 main clades (Figure 1). 


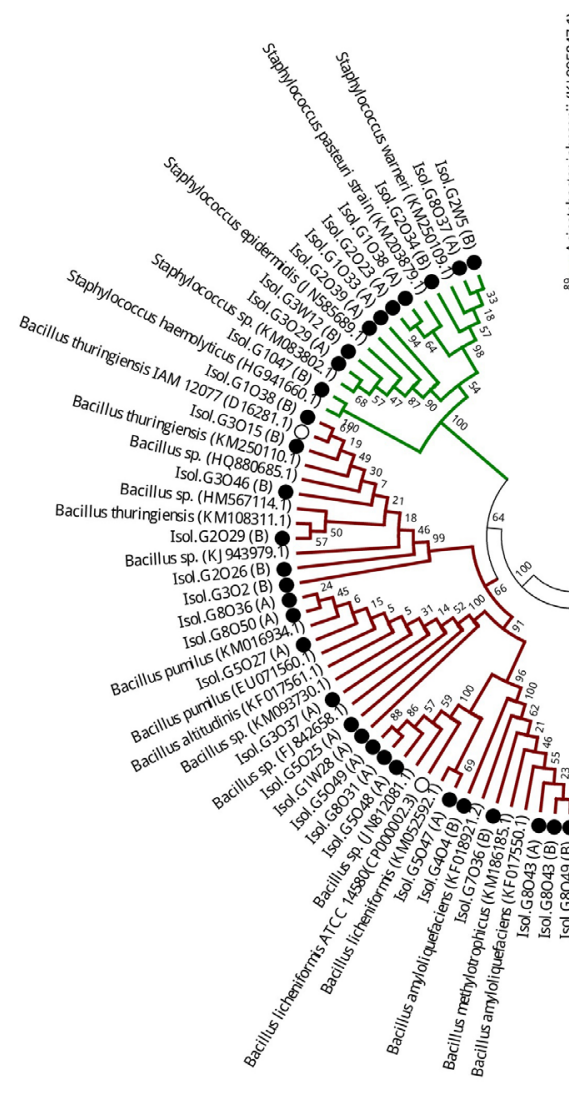

Legend:

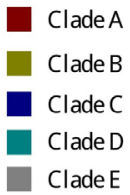

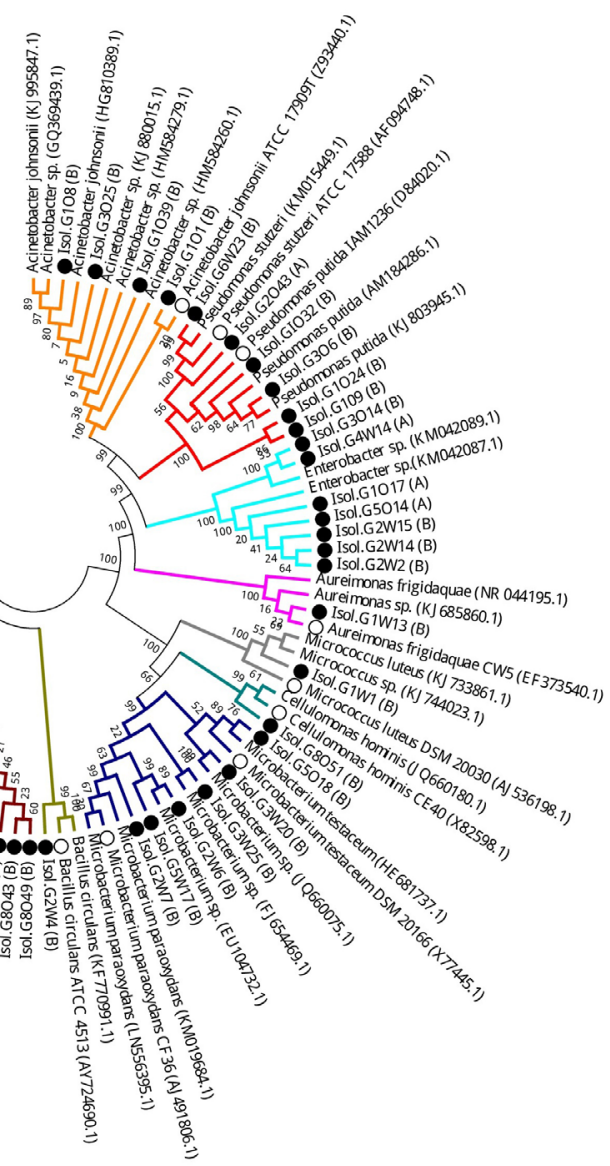

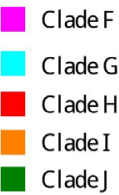

Figure 1. Phylogenetic tree of endophytic bacteria isolated from Malpighia emarginata D.C. with other bacteria deposited in GenBank, built by the neighbor-joining grouping method with the p-distance for nucleotides and the pairwise gap-deletion parameter. Numbers on the tree represent the percentage of times the right hand group occurred on the same knot during the consensus assessment (bootstrap with 10,000 replications).

The genera Bacillus was grouped into Clade A, with $99 \%$ bootstrap probability (BP), where isolates G8O43 (A), G8043 (B), and G4O4 (B) [100\% identity with Bacillus amyloliquefaciens (KF018921.2)], isolate G8049 (B) [100\% identity with Bacillus methylotrophicus (KM186185.1)], by BLAST analysis, and G7O36 (B) [100\% identified with B. amyloquefaciens (KF018921.2)] were grouped with 100\% BP with sequences deposited in GenBank, featuring different species of Bacillus. The latter were classified by molecular taxonomy as Bacillus sp. Isolate G5O47 (A) [100\% identity with Bacillus licheniformis 
(KM052592.1)] was grouped with B. licheniformis with $69 \% \mathrm{BP}$, and was identified as $B$. licheniformis. Isolates G5O48 (A) [99\% identity with B. licheniformis (KM052592.1)] by BLAST analysis, G5O49 (A) [99\% identity with Bacillus sp (JM812081.1)], and isolate G8O31 (A) [96\% identity with B. licheniformis (KM052592.1)] were grouped with $100 \%$ BP with those of isolates B. licheniformis in GenBank, and one isolate of Bacillus sp with $100 \%$ BP. These endophytic isolates were B. licheniformis. Isolate G1W28 (A) [99\% identity with Bacillus sp (KM093730.1)], G5O25 (A) [100\% identity with Bacillus sp (FJ842658.1)], G5O27 (A) [99\% identity with Bacillus pumillus (EU071560.1)], G3O37 (A) [100\% identified with B. altitudines (KF017561.1)], G8O50 (A) [100\% identified with B. pumilus (KM016935.1)], and G8O36 (A) [100\% identified with Bacillus sp (KM093730.1)] were grouped with several Bacillus species with $100 \%$ BP. These isolates should be taxonomically identified as Bacillus sp.

Also in Clade A, isolates G3O2 (B) [85\% identified with Bacillus sp (HG880685.1)], G2O26 (B) [99\% identity with Bacillus sp (KJ943979.1)], G1O38 (B) [100\% identity with Bacillus thuringiensis (KM250110.1)], G3O15 (B) [100\% identity with B. thuringiensis (KM250110.1)], G3O46 (B) [99\% identified with Bacillus sp (HM567114.1) and $B$. thuringiensis (KM108311.1)], and $\mathrm{G} 2 \mathrm{O} 29$ (B) $[100 \%$ identity with B. thuringiensis (KM108311.1)] were grouped with all B. thuringiensis strains deposited in GenBank, as well as some identified as Bacillus sp, with $99 \%$ BP. Consequently, these strains may be taxonomically identified as B. thuringiensis. In Clade B, isolate G2W4 (B) [85\% identity with Bacillus circulans (KF77099.1)] was grouped with the two isolates of B. circulans with $99 \%$ BP, and was classified as B. circulans. In Clade C, the isolate G3W20 (B) [93\% identity with Microbacterium sp (JQ660075.1)] was placed in a sub-group with several strains of Microbacterium sp with $97 \% \mathrm{BP}$, corroborating its identification at a genus level. Isolate G5O18 (B) [98\% identity with Microbacterium testaceum (HE681737.1)] was placed in a sub-group with other strains of $M$. testaceum with $89 \% \mathrm{BP}$, corroborating its identification at a species level. Isolate G3W25 (B) [99\% identity with Microbacterium sp (FJ654469.1)] was placed in a sub-group with Microbacterium sp, corroborating its identification at a genus level. Isolate G2W7 (B) [98\% identified with Microbacterium paraoxydans (LN556395.1)] was placed in a sub-group with other sequences of $M$. paraoxydans with $99 \% \mathrm{BP}$, corroborating its identification at a species level. The isolates G5W17 (B) and G2W6 (B) [99\% identified with Microbacterium sp (EU104732.1)] by BLAST analysis, were placed in a sub-group with different species of the genus Microbacterium, corroborating the molecular taxonomic identification at a genus level.

In Clade D, isolate G8O51 (B) [89\% identity with Cellulomonas sp (KF891345.1) and Cellulomonas hominis (JQ660180.1)] was placed in a sub-group with C. hominis with 99\% $\mathrm{BP}$, corroborating its identification at a species level (C. hominis).

In Clade E, isolate G1W1 (B) [99\% identity with Micrococcus sp (KJ744023.1) and Micrococcus luteus (KJ733861.1)] was placed in a sub-group with $100 \%$ BP, corroborating identification at species level as M. luteus.

In Clade F, isolate G1W13 (B) [100\% identity with Aureimonas sp (KJ685860.1) and 100\% identity with Aureimonas frigidaquae (NR044195.1)] was placed in a sub-group with isolates that had the greatest identity by BLAST analysis, at $100 \% \mathrm{BP}$, confirming the identification of this species as $A$. frigidaquae.

In Clade G, isolates G2W14 (B), G2W15 (B), G5O14 (A), G1O17 (A), and G2W2 (B) $[99,100,100,100$, and 99\% identity with Enterobacter sp (KM042087.1), respectively], 
and isolates G4W14 (A) and G3O14 (B) [100 and 100\% identity with Enterobacter sp (KM042089.1), respectively] formed a sub-group with Enterobacter sp, with 100\% BP, confirmed their identification at a genus level as Enterobacter sp.

In Clade H, endophytic isolates G3O6 (B) and G1O32 (B) [100 and 99\% identity with Pseudomonas putida (KJ803945.1), respectively], formed a sub-group with the $P$. putida subclade with $62 \% \mathrm{BP}$, corroborating their identity at a species level. Isolates G2O43 (A) and G6W23 (B) [97 and 100\% identity with Pseudomonas stutzeri (KM015449.1), respectively] formed a sub-group with $P$. stutzeri strains with $100 \% \mathrm{BP}$, corroborating their identity at a species level. Although, the isolates G109 (B) [92\% Pseudomonas putida (KJ803945.1)] and G1O24 (B) [95\% identity with P. putida (AM184286.1)], formed a subgroup with $99 \%$ BP, and with other species of Pseudomonas with $100 \%$ BP, they were identified as Pseudomonas sp.

In Clade I, isolates G1O1 (B) $[98 \%$ identity with Acinetobacter johnsonii (HG810389.1)], G1O8 (B) [99\% identity with A. johnsonii (KJ995847.1)], and endophytes G1O39 (B) and G3O25 (B) [both 100\% identity with A. johnsonii (KJ880015.1)] were grouped in Clade $\mathrm{H}$, which contains all sequences of $A$. johnsonii, confirming the taxonomic identity of the bacterial endophyte isolates at a species level.

In Clade J, the endophytic isolate G1O47 (B) [100\% identity with Staphylococcus haemolyticus (HG941660.1)] grouped with S. haemolyticus with $100 \% \mathrm{BP}$, and was taxonomically identified as S. haemolyticus. Isolates G2W5 (B), G2O34 (B), and G1O38 (A) (B) [100, 100, and 100\% identity, respectively, with Staphylococcus warneri (KM250109.1)], G8O37 (A) and G2O23 (A) [100 and 99\% identity, respectively, with Staphylococcus pasteuri (KM203879.1)], G1O33 (A) [99\% identity with S. epidermidis (JN585689.1)], G2O39 (A), G3W12 (B), and G3O29 (A) [99, 100, and 100\% identity, respectively, with Staphylococcus sp (KM083802.1)] grouped with other isolates of the genus Staphylococcus sp with 54\% BP. The molecular identification of these endophytic isolates is therefore Staphylococcus sp.

\section{Assessment of antagonistic activity of endophytic bacteria toward phytopathogenic fungi}

Although the 39 endophytic bacteria analyzed showed different levels of mycelium growth inhibition against the seven phytopathogens (Table 4), only three endophytic isolates, G4O4 (B) Bacillus amyloliquefaciens, G1W1 (B) Micrococcus sp, and G2W14 (B) Enterobacter sp, failed to show any antagonistic activity against any pathogen. Analyses of variance provided distinct groups for the pathogens analyzed for each endophyte (Table 5).

ANOVA revealed that the phytopathogen Glomerella sp had an antagonism index of $0-69.81 \%$ (Tables 4 and 5), with mean growth of the control being $8.48 \mathrm{~cm}$. Based on variation in fungal growth, four groups of isolated endophytic bacteria with inhibition activity (IA) could be statistically distinguished. Isolate $\mathrm{G} 8 \mathrm{O} 43$ (A) Bacillus $\mathrm{sp}(\mathrm{IA}=69.81 \%)$ was the best antagonist for Glomerella sp.

In the case of S. sclerotiorum, three statistically different groups were generated with antagonist indices ranging between 0 and $61.33 \%$, with special reference to antagonism by isolate G1W28 (A) Bacillus sp (IA = 61.33\%) (Figure 2). 
Table 4. Antagonistic effect of endophytic bacteria on the growth of phytopathogenic fungi.

\begin{tabular}{|c|c|c|c|c|c|c|c|}
\hline & \multicolumn{7}{|c|}{ Antagonism index (\%)* } \\
\hline Endophytic bacteria & GS** & SS & MP & DB & FS & AS & $\mathrm{FO}$ \\
\hline G1033 (A) Staphylococcus sp & $23^{\mathrm{c}}$ & $0^{\mathrm{c}}$ & $17.22^{\mathrm{b}}$ & -**** & $34.70^{\mathrm{c}}$ & $30.48^{\mathrm{d}}$ & $24.24^{\mathrm{c}}$ \\
\hline G1038 (A) Staphylococcus sp & $29.89^{c}$ & $0^{\mathrm{c}}$ & $21^{\mathrm{b}}$ & $53^{\mathrm{a}}$ & $37.45^{\mathrm{b}}$ & $29.89^{d}$ & $30.30^{\circ}$ \\
\hline G2O23 (A) Staphylococcus sp & $25.58^{\mathrm{c}}$ & $0^{\mathrm{c}}$ & $14.33^{\mathrm{b}}$ & $52.61^{\mathrm{a}}$ & $27.84^{\mathrm{c}}$ & $22.50^{\mathrm{d}}$ & $17.21^{\mathrm{c}}$ \\
\hline G2O39 (A) Staphylococcus sp & $26.29^{c}$ & $0^{c}$ & - & $43.47^{\mathrm{b}}$ & $32.58^{\mathrm{c}}$ & $29.07^{\mathrm{d}}$ & $24.12^{c}$ \\
\hline G2O43 (A) Pseudomonas stutzeri & $25.70^{\mathrm{c}}$ & $0^{\mathrm{c}}$ & $23.55^{\mathrm{b}}$ & $51.04^{\mathrm{a}}$ & $31.58^{\mathrm{c}}$ & $22.50^{\mathrm{d}}$ & $23.27^{\mathrm{c}}$ \\
\hline G3O29 (A) Staphylococcus sp & $24.41^{\mathrm{c}}$ & $0^{\mathrm{c}}$ & $21.33^{\mathrm{b}}$ & $47.65^{\mathrm{a}}$ & $28.71^{\mathrm{c}}$ & $24.97^{\mathrm{d}}$ & $29.09^{\circ}$ \\
\hline G5014 (A) Enterobacter sp & $32.78^{\mathrm{c}}$ & $21^{\mathrm{b}}$ & $32.44^{\mathrm{a}}$ & $54.56^{\mathrm{a}}$ & $30.33^{\mathrm{c}}$ & $30.71^{\mathrm{d}}$ & $29.93^{c}$ \\
\hline G5027 (A) Bacillus sp & $68.98^{\mathrm{a}}$ & $27.77^{\mathrm{b}}$ & $49.88^{\mathrm{a}}$ & - & $48.43^{b}$ & $51.81^{\mathrm{c}}$ & $56.96^{\mathrm{b}}$ \\
\hline G5047 (A) Bacillus licheniformis & $32.19^{\mathrm{c}}$ & $0^{c}$ & $27.22^{\mathrm{b}}$ & - & $26.84^{\mathrm{c}}$ & $27.19^{\mathrm{d}}$ & $25.93^{\mathrm{d}}$ \\
\hline G5048 (A) Bacillus licheniformis & $32.19^{\mathrm{c}}$ & $0^{\mathrm{c}}$ & $15.44^{\mathrm{b}}$ & $51.95^{\mathrm{a}}$ & $31.33^{\mathrm{c}}$ & $40.09^{\mathrm{d}}$ & $25.09^{\mathrm{d}}$ \\
\hline G5049 (A) Bacillus licheniformis & $24.37^{\mathrm{c}}$ & $0^{\mathrm{c}}$ & $24.33^{\mathrm{b}}$ & $37.59^{\mathrm{b}}$ & $34.08^{\mathrm{c}}$ & $25.43^{\mathrm{d}}$ & $26.66^{\mathrm{d}}$ \\
\hline G8031 (A) Bacillus licheniformis & $33.37^{\mathrm{c}}$ & $16.11^{\mathrm{b}}$ & $37.11^{\mathrm{a}}$ & $51.04^{\mathrm{a}}$ & $28.21^{\mathrm{c}}$ & $30.71^{\mathrm{d}}$ & $29.93^{\mathrm{d}}$ \\
\hline G8036 (A) Bacillus sp & $36.32^{\mathrm{c}}$ & $12.44^{\mathrm{c}}$ & $59.33^{\mathrm{a}}$ & - & $34.95^{\mathrm{c}}$ & $47.71^{\mathrm{c}}$ & $34.54^{\mathrm{d}}$ \\
\hline G8037 (A) Staphylococcus sp & $25.11^{\mathrm{c}}$ & $0^{\mathrm{c}}$ & $19.11^{\mathrm{b}}$ & $21.01^{\mathrm{c}}$ & $30.08^{\mathrm{c}}$ & $27.54^{\mathrm{d}}$ & $29.57^{\mathrm{d}}$ \\
\hline G8O43 (A) Bacillus sp & $69.81^{\mathrm{a}}$ & $25^{\mathrm{b}}$ & $57.77^{\mathrm{a}}$ & - & $69.29^{\mathrm{a}}$ & $89.09^{\mathrm{a}}$ & $70.54^{\mathrm{a}}$ \\
\hline G8050 (A) Bacillus sp & $48.34^{\mathrm{b}}$ & $37.11^{\mathrm{b}}$ & $45.55^{\mathrm{a}}$ & $61.74^{\mathrm{a}}$ & $35.58^{\mathrm{c}}$ & $40.44^{\mathrm{d}}$ & $39.39^{\mathrm{c}}$ \\
\hline G1W28 (A) Bacillus sp & $49.88^{\mathrm{b}}$ & $61.33^{\mathrm{a}}$ & $43.88^{\mathrm{a}}$ & - & $39.45^{\mathrm{b}}$ & $66.58^{\mathrm{b}}$ & $54.18^{\mathrm{b}}$ \\
\hline G4W14 (A) Enterobacter sp & $50.94^{\mathrm{b}}$ & $23.77^{\mathrm{b}}$ & $28.33^{\mathrm{b}}$ & $58.22^{\mathrm{a}}$ & $39.45^{\mathrm{b}}$ & $37.74^{\mathrm{d}}$ & $41.09^{\mathrm{c}}$ \\
\hline G1039 (B) Acinetobacter johnsonii & $27.71^{\mathrm{c}}$ & $0^{\mathfrak{c}}$ & $53.77^{\mathrm{a}}$ & - & $37.57^{\mathrm{b}}$ & $36.57^{\mathrm{d}}$ & $28.12^{\mathrm{d}}$ \\
\hline G1047 (B) Staphylococcus sp & $26.27^{\mathrm{c}}$ & $0^{\mathrm{c}}$ & $53.77^{\mathrm{a}}$ & - & $37.57^{\mathrm{b}}$ & $36.57^{\mathrm{d}}$ & $51.51^{b}$ \\
\hline G2O34 (B) Staphylococcus sp & $10.96^{\mathrm{d}}$ & $0^{c}$ & $29.66^{\mathrm{b}}$ & $63.05^{\mathrm{a}}$ & $19.35^{\mathrm{d}}$ & $37.51^{\mathrm{d}}$ & $42.42^{\mathrm{c}}$ \\
\hline G3O6 (B) Pseudomonas putida & $10.61^{\mathrm{d}}$ & $0^{\mathrm{c}}$ & $1.88^{\mathrm{b}}$ & - & $20.59^{\mathrm{d}}$ & $29.66^{\mathrm{d}}$ & $34.18^{\mathrm{d}}$ \\
\hline G3014 (B) Enterobacter sp & $26.17^{\mathrm{c}}$ & $0^{\mathrm{c}}$ & $15.55^{\mathrm{b}}$ & - & $29.71^{\mathrm{c}}$ & $23.79^{\mathrm{d}}$ & $32,36^{\mathrm{d}}$ \\
\hline G3015 (B) Bacillus thuringiensis & $33.72^{\mathrm{c}}$ & $0^{\mathrm{c}}$ & $25.44^{\mathrm{b}}$ & $56.78^{\mathrm{a}}$ & $29.96^{\mathrm{C}}$ & $25.55^{\mathrm{d}}$ & $19.27^{\mathrm{e}}$ \\
\hline G3O25 (B) Acinetobacter johnsonii & $44.45^{\mathrm{b}}$ & $0^{c}$ & $47.77^{\mathrm{a}}$ & - & $20.97^{\mathrm{d}}$ & $21.92^{\mathrm{d}}$ & $26.30^{\mathrm{d}}$ \\
\hline G4O4 (B) Bacillus sp & - & - & - & - & - & - & - \\
\hline G5018 (B) Microbacterium testaceum & $26.29^{\mathrm{c}}$ & $30.55^{\mathrm{b}}$ & $13.88^{\mathrm{b}}$ & - & $25.34^{\mathrm{c}}$ & $24.85^{\mathrm{d}}$ & $19.87^{\mathrm{e}}$ \\
\hline G8051 (B) Cellulomonas hominis & $27.94^{\mathrm{c}}$ & $0^{\mathrm{c}}$ & $0^{\mathrm{b}}$ & - & $26.59^{\mathrm{c}}$ & $17.58^{\mathrm{d}}$ & $11.15^{\mathrm{e}}$ \\
\hline G1W1 (B) Micrococcus luteus & - & - & - & - & - & - & - \\
\hline G1W13 (B) Aureimonas frigidaquae & $13.32^{\mathrm{d}}$ & $0^{\mathrm{c}}$ & $12.11^{\mathrm{b}}$ & $36.94^{\mathrm{b}}$ & $16.85^{\mathrm{d}}$ & $18.17^{\mathrm{d}}$ & $6.06^{\mathrm{e}}$ \\
\hline G2W2 (B) Enterobacter $\mathrm{sp}$ & $30.42^{\mathrm{c}}$ & $24.66^{\mathrm{b}}$ & $35.22^{\mathrm{a}}$ & - & $29.71^{\mathrm{c}}$ & $26.14^{\mathrm{d}}$ & $34.54^{\mathrm{d}}$ \\
\hline G2W4 (B) Bacillus circulans & $30.66^{\mathrm{c}}$ & $0^{c}$ & - & - & $24.96^{\mathrm{c}}$ & $21.10^{\mathrm{d}}$ & $14.18^{\mathrm{e}}$ \\
\hline G2W5 (B) Staphylococcus sp & $34.19^{c}$ & $0^{\mathrm{c}}$ & $46.00^{\mathrm{a}}$ & - & $47.81^{b}$ & $46.89^{\mathrm{c}}$ & $41.61^{\mathrm{c}}$ \\
\hline G2W6 (B) Microbacterium sp & $26.88^{\mathrm{c}}$ & $0^{c}$ & $35.44^{\mathrm{a}}$ & $56.26^{\mathrm{a}}$ & $30.33^{\mathrm{c}}$ & $22.50^{\mathrm{d}}$ & $13.81^{\mathrm{e}}$ \\
\hline G2W14 (B) Enterobacter sp & - & - & - & - & - & - & - \\
\hline G2W15 (B) Enterobacter sp & $68.16^{\mathrm{a}}$ & $34.33^{\mathrm{b}}$ & $31.11^{\mathrm{b}}$ & $52.21^{\mathrm{a}}$ & $43.82^{b}$ & $47.12^{\mathrm{c}}$ & $43.51^{\mathrm{c}}$ \\
\hline G3W25 (B) Microbacterium sp & $43.98^{\mathrm{b}}$ & $0^{\mathrm{c}}$ & $18.22^{\mathrm{b}}$ & - & $24.46^{\mathrm{c}}$ & $20.75^{\mathrm{d}}$ & $14.78^{\mathrm{e}}$ \\
\hline G5W17 (B) Microbacterium sp & $51.06^{\mathrm{b}}$ & $0^{\mathrm{c}}$ & $8.33^{\mathrm{b}}$ & $33.28^{\mathrm{b}}$ & $34.33^{\mathrm{c}}$ & $13.24^{\mathrm{d}}$ & $30.78^{\mathrm{d}}$ \\
\hline G6W23 (B) Pseudomonas stutzeri & $35.96^{\mathrm{C}}$ & $0^{\mathrm{c}}$ & $13.00^{\mathrm{b}}$ & $39.16^{\mathrm{b}}$ & $48.06^{\mathrm{b}}$ & $20.51^{\mathrm{d}}$ & $27.75^{\mathrm{d}}$ \\
\hline Control $1 * * * *$ & $0^{\mathrm{d}}$ & $0^{\mathrm{c}}$ & $0^{\mathrm{b}}$ & $0^{\mathrm{d}}$ & $0^{\mathrm{e}}$ & $0^{\mathrm{d}}$ & $0^{\mathrm{e}}$ \\
\hline Control $2 * * * * *$ & $0^{\mathrm{d}}$ & $0^{c}$ & $0^{\mathrm{b}}$ & $0^{\mathrm{d}}$ & $0^{e}$ & $0^{\mathrm{d}}$ & $0^{\mathrm{e}}$ \\
\hline
\end{tabular}

*Means of triplicate experiments followed by the same letter in the column did not differ by Scott-Knott's test $(\mathrm{P}<0.05)$. **Phytopathogenic fungi: GS: Glomerella sp; SS: Sclerotinia sclerotiorum; MP: Moniliophtora perniciosa; DB: Dydmella bryoniae; FS: Fusarium solani; AS: Alternaria sp; FO: Fusarium oxysporum. ***No antagonism. ****Control $1=$ Petri plate with phytopathogens only (growth - diameter in $\mathrm{cm}$, equivalent to $0 \%$ antagonism). ${ }^{* * * * *}$ Control $2=$ Petri plate with two $6-\mathrm{mm}$ discs of phytopathogens inoculated on the edges, equidistant at $4 \mathrm{~cm}$ (growth - diameter in $\mathrm{cm}$, equivalent to $0 \%$ antagonism).

The M. perniciosa growth reduction by endophytes presents results in two statistically distinct groups of antagonism index. The isolate G8O43 (A) Bacillus sp had the greatest IA $(57.77 \%)$.

Of note, the pathogen Didymella bryoniae had the least number of antagonists (48.71\%) of the 39 bacterial isolates. Antagonism indices varied between 21.01 and $63.05 \%$. Isolate $\mathrm{G} 2 \mathrm{O} 34$ (B) Staphylococcus sp (IA = 63.05\%) was the most effective antagonist.

To Fusarium solani, five different statistical groups of IA and four groups to Alternaria sp were obtained. Antagonism indexes for $F$. solani ranged between 16.85 and $69.29 \%$, whereas for Alternaria sp, indices ranged between 0 and $89.09 \%$. The endophytic isolate G8O43 (A) Bacillus sp was the most effective antagonist against the two phytopathogens.

The antagonism index of endophytic bacteria against Fusarium oxysporum, the phytopathogen that causes fusariosis in acerola, ranged from 0 to $70.54 \%$, with the highest 
Table 5. Antagonistic effect of endophytic bacteria on the growth of phytopathogenic fungi.

\begin{tabular}{|c|c|c|c|}
\hline Phytopathogens & Grouping & Antagonism index (\%)* & No. of endophytes \\
\hline \multirow[t]{4}{*}{ Glomerella $\mathrm{sp}$} & $\mathrm{A}$ & 69.81-68.16 & 3 \\
\hline & B & $51.06-43.98$ & 6 \\
\hline & $\mathrm{C}$ & $36.32-23.00$ & 24 \\
\hline & $\mathrm{D}^{* *}$ & $13.32-0$ & 3 \\
\hline \multirow[t]{3}{*}{ Sclerotinia sclerotiorum } & $\mathrm{A}$ & 61.33 & 1 \\
\hline & $\mathrm{B}$ & $37.11-16.11$ & 9 \\
\hline & $\mathrm{C}^{* *}$ & $12.44-0$ & 26 \\
\hline \multirow[t]{2}{*}{ Moniliophtora perniciosa } & A & $59.33-32.44$ & 13 \\
\hline & $\mathrm{B}^{* *}$ & $31.11-0$ & 22 \\
\hline \multirow[t]{4}{*}{ Dydmella bryoniae } & A & $63.05-47.65$ & 13 \\
\hline & $\mathrm{B}$ & $43.47-33.28$ & 5 \\
\hline & $\mathrm{C}$ & 21.01 & 1 \\
\hline & $\mathrm{D}^{* *}$ & 0 & - \\
\hline \multirow[t]{5}{*}{ Fusarium solani } & $\mathrm{A}$ & 69.29 & 1 \\
\hline & B & $48.43-37.45$ & 9 \\
\hline & $\mathrm{C}$ & $35.58-24.46$ & 22 \\
\hline & $\mathrm{D}$ & $20.97-16.85$ & 4 \\
\hline & $\mathrm{E}^{* *}$ & 0 & - \\
\hline \multirow[t]{4}{*}{ Alternaria $\mathrm{sp}$} & A & 89.09 & 1 \\
\hline & $\mathrm{B}$ & 66.58 & 1 \\
\hline & $\mathrm{C}$ & $51.81-46.89$ & 4 \\
\hline & $\mathrm{D}^{* *}$ & $40.44-0$ & 30 \\
\hline \multirow[t]{5}{*}{ Fusarium oxysporum } & $\mathrm{A}$ & 70.54 & 1 \\
\hline & $\mathrm{B}$ & $56.96-51.51$ & 3 \\
\hline & $\mathrm{C}$ & $43.51-39.39$ & 5 \\
\hline & $\mathrm{D}$ & $34.54-23.27$ & 19 \\
\hline & $\mathrm{E}^{* * *}$ & $19.87-0$ & 8 \\
\hline
\end{tabular}

*Means of triplicate experiments compared by the Scott-Knott test $(\mathrm{P}<0.05) .{ }^{* *}$ Controls are also in this group.

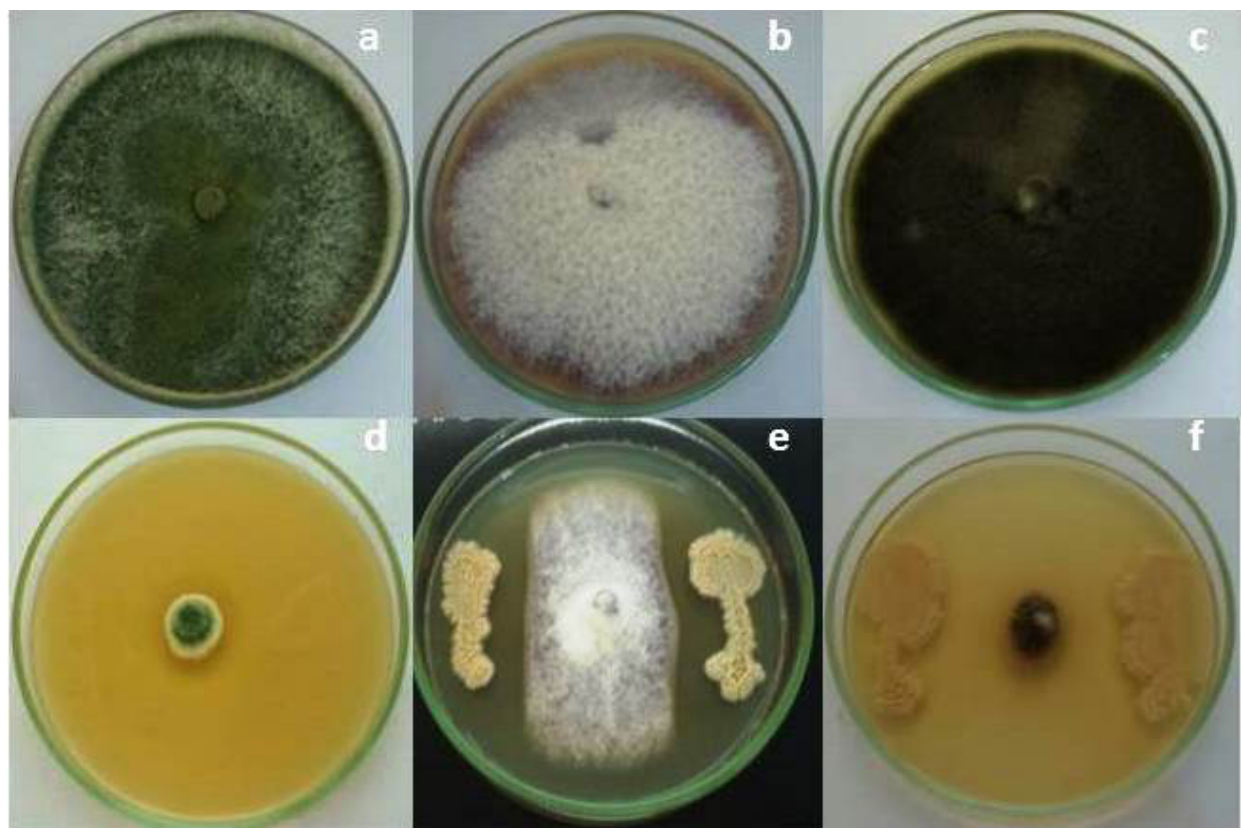

Figure 2. Antagonistic activity of endophytic bacterial isolated from Malpighia emarginata against phytopathogens. a. phytopathogen Sclerotinia sclorotiorum; b. Fusarium oxysporum; c. Alternaria sp; d. antagonism mediated by isolate G1W28 (A) (Bacillus sp) against S. sclorotiorum; e. antagonism mediated by isolate G8O43 (A) Bacillus sp against F. oxysporum; f. antagonism mediated by isolate G8O43 (A) (Bacillus sp) against Alternaria sp. 
indices obtained by the four isolates: G8O43 (A) Bacillus sp with (IA = 70.54\%); G5O27 (A) Bacillus sp; G1W28 (A) Bacillus sp; and G1O47 (B) Staphylococcus sp. Variation among these isolates ranged between 51.51 and $56.96 \%$ in group B.

\section{Enzymatic activity of endophytic isolates}

Thirty-four endophytic bacteria isolated from M. emarginata were assessed for their enzymatic activity with regard to the production of protease, amylase, pectinase, lipase, esterase, cellulase, and xylanase. Protease accounted for the highest percentage $(44.11 \%)$ of enzyme produced by M. emarginata endophytic bacteria isolates; followed by lipase (38.23\%), amylase and pectinase $(26.47 \%)$, and esterase $(14.70 \%)$, whereas cellulase and xylanase had the lowest $(11.76 \%)$ (Table 6).

Table 6. Protease, amylase, pectinase, lipase, esterase, cellulase, and xylanase activity of endophytic bacteria from Malpighia emarginata, reported as enzymatic index $(\mathrm{EI}) \pm$ standard deviation.

\begin{tabular}{|c|c|c|c|c|c|c|c|}
\hline \multirow{2}{*}{ Endophytic bacteria } & \multicolumn{7}{|c|}{ Enzymatic index $(\mathrm{EI})^{*}$} \\
\hline & Protease & Amylase & Pectinase & Lipase & Esterase & Cellulase & Xylanase \\
\hline G2O23 (A) Staphylococcus sp & $3.56 \pm 0.41^{\mathrm{b}}$ & $0.00 \pm \pm 0.00^{f}$ & $0.00 \pm 0.00 \mathrm{~g}$ & $0.00 \pm 0.00^{\mathrm{f}}$ & $0.00 \pm 0.00^{c}$ & $0.00 \pm 0.00^{\circ}$ & $0.00 \pm 0.00^{\mathrm{d}}$ \\
\hline G2O39 (A) Staphylococcus sp & $4.80 \pm 0.33^{\mathrm{a}}$ & $1.25 \pm 0.12^{\mathrm{e}}$ & $0.00 \pm 0.00^{\mathrm{g}}$ & $0.00 \pm 0.00^{\mathrm{f}}$ & $0.00 \pm 0.00^{\circ}$ & $0.00 \pm 0.00^{\circ}$ & $0.00 \pm 0.00^{\mathrm{d}}$ \\
\hline G2O43 (A) Pseudomonas stutzeri & $0.00 \pm 0.00^{\mathrm{g}}$ & $2.15 \pm 0.35^{\mathrm{b}}$ & $2.30 \pm 0.34^{\mathrm{b}}$ & $0.00 \pm 0.00^{f}$ & $0.00 \pm 0.00^{c}$ & $0.00 \pm 0.00^{\circ}$ & $0.00 \pm 0.00^{\mathrm{d}}$ \\
\hline G3O29 (A) Staphylococcus sp & $2.96 \pm 0.18^{\mathrm{c}}$ & $0.00 \pm 0.00^{\mathrm{f}}$ & $0.00 \pm 0.00^{\mathrm{g}}$ & $0.00 \pm 0.00^{\mathrm{f}}$ & $0.00 \pm 0.00^{\circ}$ & $0.00 \pm 0.00^{\mathrm{c}}$ & $0.00 \pm 0.00^{\mathrm{d}}$ \\
\hline G5O14 (A) Enterobacter $\mathrm{sp}$ & $0.00 \pm 0.00^{8}$ & $0.00 \pm 0.00^{\mathrm{f}}$ & $0.00 \pm 0.00^{\mathrm{g}}$ & $0.00 \pm 0.00^{\mathrm{f}}$ & $0.00 \pm 0.00^{c}$ & $0.00 \pm 0.00^{\mathrm{c}}$ & $0.00 \pm 0.00^{\mathrm{d}}$ \\
\hline G5027 (A) Bacillus sp & $3.83 \pm 0.37^{\mathrm{b}}$ & $0.00 \pm 0.00^{f}$ & $0.00 \pm 0.00^{\mathrm{g}}$ & $1.55 \pm 0.15^{\mathrm{c}}$ & $0.00 \pm 0.00^{\circ}$ & $0.00 \pm 0.00^{\mathrm{c}}$ & $0.00 \pm 0.00^{\mathrm{d}}$ \\
\hline G5047 (A) Bacillus licheniformis & $0.00 \pm 0.00^{\mathrm{g}}$ & $0.00 \pm 0.00^{f}$ & $1.32 \pm 0.19^{\mathrm{c}}$ & $1.72 \pm 0.19^{\mathrm{b}}$ & $0.00 \pm 0.00^{\circ}$ & $0.00 \pm 0.00^{\circ}$ & $0.00 \pm 0.00^{\mathrm{d}}$ \\
\hline G8037 (A) Staphylococcus sp & $2.97 \pm 0.4^{\mathrm{c}}$ & $0.00 \pm 0.00^{f}$ & $0.00 \pm 0.00^{\mathrm{g}}$ & $0.00 \pm 0.00^{f}$ & $0.00 \pm 0.00^{\circ}$ & $0.00 \pm 0.00^{\mathrm{c}}$ & $0.00 \pm 0.00^{\mathrm{d}}$ \\
\hline G8043 (A) Bacillus sp & $2.22 \pm 0.45^{\mathrm{d}}$ & $1.34 \pm 0.20^{\mathrm{e}}$ & $0.00 \pm 0.00^{\mathrm{g}}$ & $0.00 \pm 0.00^{f}$ & $0.00 \pm 0.00^{\mathrm{c}}$ & $0.00 \pm 0.00^{\mathrm{c}}$ & $0.00 \pm 0.00^{\mathrm{d}}$ \\
\hline G8050 (A) Bacillus sp & $3.42 \pm 0.39^{\mathrm{b}}$ & $0.00 \pm 0.00^{\mathrm{f}}$ & $0.00 \pm 0.00 \mathrm{~g}$ & $1.49 \pm 0.11^{\mathrm{d}}$ & $0.00 \pm 0.00^{c}$ & $0.00 \pm 0.00^{c}$ & $0.00 \pm 0.00^{\mathrm{d}}$ \\
\hline G1W28 (A) Bacillus sp & $0.00 \pm 0.00^{\mathrm{g}}$ & $0.00 \pm 0.00^{f}$ & $0.00 \pm 0.00^{\mathrm{g}}$ & $1.24 \pm 0.09^{\mathrm{c}}$ & $0.00 \pm 0.00^{\circ}$ & $0.00 \pm 0.00^{\mathrm{c}}$ & $0.00 \pm 0.00^{\mathrm{d}}$ \\
\hline G4W14 (A) Enterobacter sp & $0.00 \pm 0.00^{\mathrm{g}}$ & $0.00 \pm 0.00^{\mathrm{f}}$ & $0.00 \pm 0.00^{\mathrm{g}}$ & $0.00 \pm 0.00^{f}$ & $0.00 \pm 0.00^{\circ}$ & $0.00 \pm 0.00^{\circ}$ & $0.00 \pm 0.00^{\mathrm{d}}$ \\
\hline G109 (B) Pseudomonas putida & $0.00 \pm 0.00^{\mathrm{g}}$ & $0.00 \pm 0.00^{\mathrm{f}}$ & $0.00 \pm 0.00^{\mathrm{g}}$ & $0.00 \pm 0.00^{\mathrm{f}}$ & $0.00 \pm 0.00^{\circ}$ & $0.00 \pm 0.00^{\mathrm{c}}$ & $0.00 \pm 0.00^{\mathrm{d}}$ \\
\hline G1024 (B) Pseudomonas putida & $0.00 \pm 0.00^{\mathrm{g}}$ & $0.00 \pm 0.00^{f}$ & $0.00 \pm 0.00^{\mathrm{g}}$ & $0.00 \pm 0.00^{\mathrm{f}}$ & $0.00 \pm 0.00^{\circ}$ & $0.00 \pm 0.00^{\circ}$ & $0.00 \pm 0.00^{\mathrm{d}}$ \\
\hline G1032 (B) Pseudomonas putida & $0.00 \pm 0.00^{\mathrm{g}}$ & $0.00 \pm 0.00^{\mathrm{f}}$ & $0.00 \pm 0.00^{\mathrm{g}}$ & $0.00 \pm 0.00^{\mathrm{f}}$ & $0.00 \pm 0.00^{c}$ & $0.00 \pm 0.00^{\mathrm{c}}$ & $0.00 \pm 0.00^{\mathrm{d}}$ \\
\hline G1O38 (B) Bacillus thurigiensis & $2.17 \pm 0.35^{\mathrm{d}}$ & $1.65 \pm 0.15^{\mathrm{c}}$ & $2.21 \pm 0.14^{\mathrm{b}}$ & $1.57 \pm 0.26^{\mathrm{d}}$ & $1.23 \pm 0.06^{\mathrm{b}}$ & $1.41 \pm 0.08^{b}$ & $0.00 \pm 0.00^{\mathrm{d}}$ \\
\hline G1O39 (B) Acinetobacter johnsonii & $0.00 \pm 0.00^{\mathrm{g}}$ & $0.00 \pm 0.00^{f}$ & $0.00 \pm 0.00^{\mathrm{g}}$ & $2.03 \pm 0.16^{\mathrm{a}}$ & $0.00 \pm 0.00^{\circ}$ & $0.00 \pm 0.00^{\mathrm{c}}$ & $0.00 \pm 0.00^{\mathrm{d}}$ \\
\hline G1O47 (B) Staphylococcus sp & $4.39 \pm 1.19^{\mathrm{a}}$ & $0.00 \pm 0.00^{f}$ & $0.00 \pm 0.00^{\mathrm{g}}$ & $0.00 \pm 0.00^{f}$ & $0.00 \pm 0.00^{\mathrm{c}}$ & $0.00 \pm 0.00^{\mathrm{c}}$ & $0.00 \pm 0.00^{\mathrm{d}}$ \\
\hline G2O26 (B) Bacillus tequilensis & $2.69 \pm 0.41^{\mathrm{c}}$ & $1.73 \pm 0.15^{\mathrm{c}}$ & $2.32 \pm 0.24^{\mathrm{b}}$ & $1.73 \pm 0.16^{\mathrm{b}}$ & $1.21 \pm 0.03^{\mathrm{b}}$ & $1.41 \pm 0.09^{\mathrm{b}}$ & $1.53 \pm 0.16^{\mathrm{c}}$ \\
\hline G3O2 (B) Bacillus sp & $2.15 \pm 0.21^{\mathrm{d}}$ & $1.77 \pm 0.11^{\mathrm{c}}$ & $2.26 \pm 0.31^{\mathrm{b}}$ & $1.35 \pm 0.06^{\mathrm{e}}$ & $0.00 \pm 0.00^{\circ}$ & $1.39 \pm 0.07^{\mathrm{b}}$ & $1.52 \pm 0.14^{\mathrm{c}}$ \\
\hline G306 (B) Pseudomonas putida & $0.00 \pm 0.00^{\mathrm{g}}$ & $0.00 \pm 0.00^{f}$ & $0.00 \pm 0.00^{\mathrm{g}}$ & $0.00 \pm 0.00^{f}$ & $0.00 \pm 0.00^{c}$ & $0.00 \pm 0.00^{\circ}$ & $0.00 \pm 0.00^{\mathrm{d}}$ \\
\hline G3O25 (B) Acinetobacter johnsonii & $0.00 \pm 0.00^{\mathrm{g}}$ & $1.29 \pm 0.05^{\mathrm{e}}$ & $0.00 \pm 0.00^{\mathrm{g}}$ & $2.14 \pm 0.16^{\mathrm{a}}$ & $1.62 \pm 0.13^{\mathrm{a}}$ & $0.00 \pm 0.00^{\circ}$ & $0.00 \pm 0.00^{\mathrm{d}}$ \\
\hline G5018 (B) Microbacterium testaceum & $3.01 \pm 0.24^{\mathrm{c}}$ & $0.00 \pm 0.00^{f}$ & $1.65 \pm 0.15^{\mathrm{d}}$ & $0.00 \pm 0.00^{\mathrm{f}}$ & $0.00 \pm 0.00^{\circ}$ & $1.94 \pm 0.10^{\mathrm{a}}$ & $0.00 \pm 0.00^{\mathrm{d}}$ \\
\hline G7036 (B) Bacillus sp & $0.00 \pm 0.00^{\mathrm{g}}$ & $0.00 \pm 0.00^{f}$ & $0.00 \pm 0.00^{\mathrm{g}}$ & $0.00 \pm 0.00^{f}$ & $0.00 \pm 0.00^{c}$ & $0.00 \pm 0.00^{\circ}$ & $0.00 \pm 0.00^{\mathrm{d}}$ \\
\hline G108 (B) Acinetobacter johnsonii & $0.00 \pm 0.00 \mathrm{~g}$ & $0.00 \pm 0.00^{f}$ & $1.12 \pm 0.05^{f}$ & $1.49 \pm 0.19^{\mathrm{d}}$ & $0.00 \pm 0.00^{\circ}$ & $0.00 \pm 0.00^{\mathrm{c}}$ & $0.00 \pm 0.00^{\mathrm{d}}$ \\
\hline G2O29 (B) Bacillus thuringiensis & $1.32 \pm 0.10^{\circ}$ & $1.48 \pm 0.33^{\mathrm{d}}$ & $1.82 \pm 0.21^{\mathrm{c}}$ & $1.66 \pm 0.24^{\mathrm{b}}$ & $1.20 \pm 0.10^{\mathrm{b}}$ & $0.00 \pm 0.00^{\mathrm{c}}$ & $0.00 \pm 0.00^{\mathrm{d}}$ \\
\hline G3015 (B) Bacillus thuringiensis & $1.25 \pm 0.07^{\mathrm{e}}$ & $1.60 \pm 0.28^{\mathrm{c}}$ & $1.89 \pm 0.16^{\mathrm{c}}$ & $1.60 \pm 0.16^{\mathrm{c}}$ & $1.22 \pm 0.08^{b}$ & $0.00 \pm 0.00^{\circ}$ & $0.00 \pm 0.00^{\mathrm{d}}$ \\
\hline G8O49 (B) Bacillus sp & $0.00 \pm 0.00^{\mathrm{g}}$ & $0.00 \pm 0.00^{\mathrm{f}}$ & $0.00 \pm 0.00^{\mathrm{g}}$ & $0.00 \pm 0.00^{\mathrm{f}}$ & $0.00 \pm 0.00^{\mathrm{c}}$ & $0.00 \pm 0.00^{\mathrm{c}}$ & $0.00 \pm 0.00^{\mathrm{d}}$ \\
\hline G8051 (B) Cellulomonas hominis & $0.00 \pm 0.00 \mathrm{~g}$ & $0.00 \pm 0.00^{\mathrm{f}}$ & $0.00 \pm 0.00 \mathrm{~g}$ & $1.74 \pm 0.37^{\mathrm{b}}$ & $0.00 \pm 0.00^{\circ}$ & $0.00 \pm 0.00^{\mathrm{c}}$ & $0.00 \pm 0.00^{\mathrm{d}}$ \\
\hline G1W1 (B) Micrococcus luteus & $0.00 \pm 0.00^{\mathrm{g}}$ & $0.00 \pm 0.00^{\mathrm{f}}$ & $0.00 \pm 0.00^{\mathrm{g}}$ & $0.00 \pm 0.00^{\mathrm{f}}$ & $0.00 \pm 0.00^{\mathrm{c}}$ & $0.00 \pm 0.00^{\mathrm{c}}$ & $2.48 \pm 0.26^{\mathrm{a}}$ \\
\hline G1W13 (B) Aureimonas frigidaquae & $0.00 \pm 0.00^{\mathrm{g}}$ & $0.00 \pm 0.00^{f}$ & $0.00 \pm 0.00^{\mathrm{g}}$ & $0.00 \pm 0.00^{\mathrm{f}}$ & $0.00 \pm 0.00^{\circ}$ & $0.00 \pm 0.00^{\mathrm{c}}$ & $0.00 \pm 0.00^{\mathrm{d}}$ \\
\hline G3W20 (B) Microbacterium sp & $0.00 \pm 0.00^{\mathrm{g}}$ & $0.00 \pm 0.00^{f}$ & $0.00 \pm 0.00^{\mathrm{g}}$ & $0.00 \pm 0.00^{f}$ & $0.00 \pm 0.00^{\circ}$ & $0.00 \pm 0.00^{\mathrm{c}}$ & $0.00 \pm 0.00^{\mathrm{d}}$ \\
\hline G5W17 (B) Microbacterium sp & $0.00 \pm 0.00^{\mathrm{g}}$ & $0.00 \pm 0.00^{\mathrm{f}}$ & $0.00 \pm 0.00^{\mathrm{g}}$ & $0.00 \pm 0.00^{\mathrm{f}}$ & $0.00 \pm 0.00^{c}$ & $0.00 \pm 0.00^{\mathrm{c}}$ & $0.00 \pm 0.00^{\mathrm{d}}$ \\
\hline G6W23 (B) Pseudomonas stutzeri & $\frac{0.00 \pm 0.00^{f}}{1.20 \pm 0.06}$ & $0.00 \pm 0.000^{f}$ & $0.00 \pm 0.00^{\mathrm{g}}$ & $0.00 \pm 0.000^{\mathrm{f}}$ & $0.00 \pm 0.00^{\mathrm{c}}$ & $0.00 \pm 0.000^{\mathrm{c}}$ & $2.01 \pm 0.28^{\mathrm{b}}$ \\
\hline Positive control** & $3.34 \pm 0.45^{\mathrm{b}}$ & $3.00 \pm 0.00^{\mathrm{a}}$ & $3.42 \pm 0.15^{\mathrm{a}}$ & & - & & \\
\hline Negative control*** & $0.00 \pm 0.00^{\mathrm{g}}$ & $0.00 \pm 0.00^{f}$ & $0.00 \pm 0.00^{\mathrm{g}}$ & $0.00 \pm 0.00^{\mathrm{f}}$ & $0.00 \pm 0.00^{\circ}$ & $0.00 \pm 0.00^{\mathrm{c}}$ & $0.00 \pm 0.00^{\mathrm{d}}$ \\
\hline
\end{tabular}

*Means followed by the same letter in the column do not differ by the Scott-Knott test $(\mathrm{P}<0.05)$. **Positive control directly applied to the solid medium. Commercial enzymes: Protease - Aspergillus oryzae, $\alpha$-amylase porcine pancreatic, Pectinase - Aspergillus niger (Sigma). ***Negative control directly applied in the solid medium. (1\%) Saline solution

ANOVA demonstrated significant differences for the enzymatic activity of protease (Table 6), where the EI ranged from 1.20 for G6W23 (B) P. stutzeri to 4.80 for G2O39 (A) Staphylococcus sp. Twelve of the endophytic bacterial isolates had an EI above 2.

In the case of amylase, there was a statistical difference between endophytes with regard to enzyme production, especially for isolate G2O43 (A) (P. stutzeri) with an index of 2.15. Pectin indices ranged from 1.12 to 2.32 , with the best noted for the endophytes G1O38 (B) Bacillus thuringiensis (EI = 2.21), G3O2 (B) Bacillus sp (EI = 2.26), G2O43 (A) 
Pseudomonas stutzeri $(\mathrm{EI}=2.30)$, and G2O26 (B) Bacillus $\mathrm{sp}(\mathrm{EI}=2.26)$.

Enzymatic variation for lipase (Table 6) ranged from 1.24 for G1W28 (A) (Bacillus $\mathrm{sp})$ to 2.14 for $\mathrm{G} 3 \mathrm{O} 25$ (B) (Acinetobacter johnsonii), which showed the highest index for esterase (EI = 1.62). G2O29 (B) (Bacillus thuringiensis) had the lowest index to esterase $(\mathrm{EI}=1.20)$. To cellulase, the higher EI was obtained by isolate G5O18 (B) (Microbacterium testaceum $(\mathrm{EI}=1.94)$. Four isolates show positive results for cellulase.

Similar to cellulase, the enzymatic activity of xylanase from endophytes also revealed positive results in four isolates, with indices between 1.52 and 2.48. The latter was found for the isolate G1W1 (B) (Micrococcus luteus).

These results showed that the isolate G2O39 (A) Staphylococcus sp possessed the greatest EI of all the tested isolates (Figure 3), with an EI of 4.80 for protease. This was significantly higher than that observed for the positive control commercial enzyme Protease - Aspergillus oryzae $(\mathrm{EI}=3.34)$. In the case of other commercial enzymes used as positive controls $(\alpha$-amylase porcine pancreatic enzyme and pectinase from Aspergillus niger), the EI ranging between 3.00 and 3.42, respectively, were statistically higher than endophytic bacteria tested.

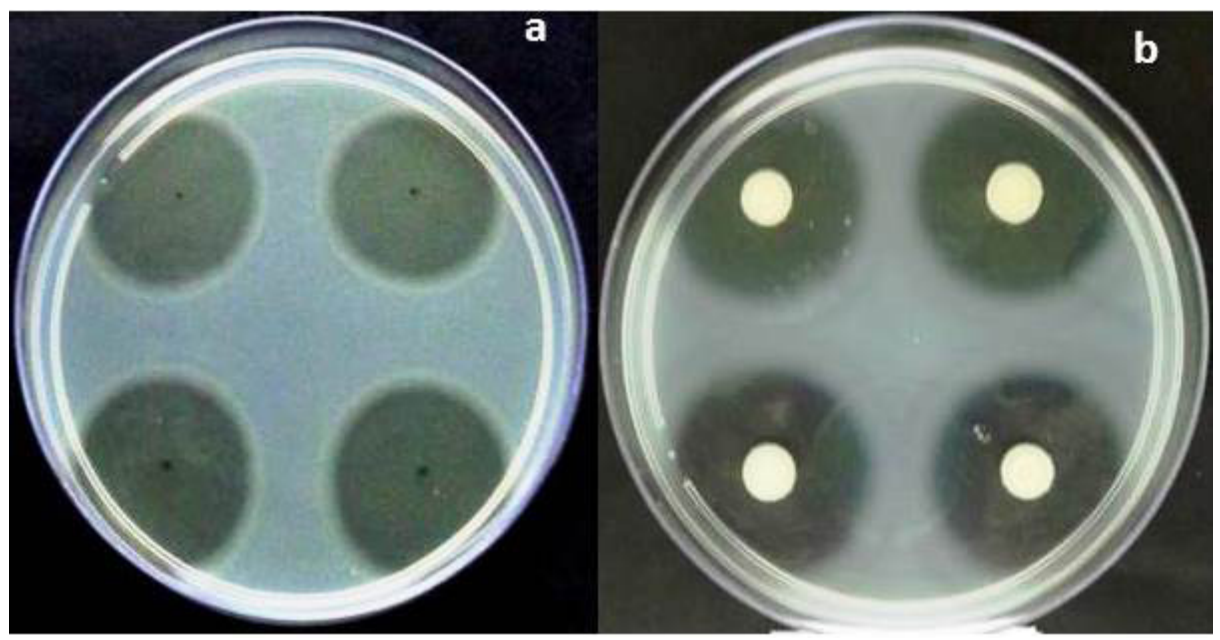

Figure 3. Proteolytic activity of isolates from Malpighia emarginata: a. protease extracted from Aspergillus oryzae (positive control); b. G2O39 (A) Staphylococcus sp.

\section{DISCUSSION}

Sampled leaf fragments had low colonization frequency, with indices ranging from 10.4 to $21.2 \%$, which may be due to several factors such as climate, rainfall, temperature, humidity, and the age of plants. In fact, Arnold and Herre (2003) noted that these factors affect the occurrence of endophytes. After isolation, many endophytes could not be cultivated, perhaps due to their need of culture media or specific conditions for growth (Lacava et al., 2006).

In their research on the isolation and identification of endophytic bacteria of cassava from three Brazilian States (São Paulo, Amazonas, and Bahia), Teixeira et al., (2007) listed 27 genera, with the most frequent being Bacillus, Burkholderia, Enterobacter, Escherichia, Salmonella, Stenotrophomonas, and Serratia. 
West et al. (2010) isolated endophytic bacteria from several tissues of grapevine including the stem, root, and leaves. Most endophytes were isolated from roots, with the genus Bacillus spp (26\% of total) being the most frequently identified strain, as well as the most frequent genus found in leaves. B. cereus, B. lentimorbus, B. thuringiensis, B. megaterium, and $B$. case $i$ were among the species isolated, as were species of the genera Pseudomonas spp, Curtobacterium spp, Streptomyces spp, as well as Enterobacter cloacae.

Seo et al. (2010) isolated endophytic bacteria from radish leaves and roots. Leaf samples produced 140 isolates from 14 species, including Enterobacter sp, B. subtilis, B. licheniformis, Stenotrophomonas maltophilia, Pseudomonas sp, Myroides odoratimimus, Microbacterium sp, Citrobacter freundii, and others.

The taxonomic identity of several endophytes isolated from $M$. emarginata was based on molecular phylogenetic analysis by comparing ITS sequences of endophytes isolated with those deposited in GenBank, also considering the type strain sequences (when present in LPSN databases), by BLASTn. Comparison with type strain sequences provided identity rates above 90\%, except for those verified for isolates G2W4 (B) and G8051 (B) (Table 2).

Among the endophytic bacteria from M. emarginata leaves, the presence of several genera was consistent with the results of previous studies. In most studies, the most abundant group was found to be Bacillus, similar to the results of the current study, in which 21 isolates were identified. These formed the most populous clade, accounting for $36.20 \%$ of the endophytes under analysis, with $19.04 \%$ identified as $B$. licheniformis, an endophyte species isolated from the leaves and roots of radish by Seo et al. (2010), and $19.04 \%$ identified as $B$. thuringiensis, an endophyte species in grape isolates reported by West et al. (2010) in isolates of banana leaves registered by Souza et al. (2014).

The genus Staphylococcus, which ranked second in the number of acerola isolates, was also isolated from potato. Its positive activity was also reported in an assay for growth enhancement in plants (Sessitsch et al., 2004).

Lacava et al. (2006) characterized the endophytic bacterial community of citrus and investigated its relationship with the occurrence of citrus variegated chlorosis (CVC). In asymptomatic plants, the endophyte community has been reported to be composed of the genera Klebsiella sp, Acinetobacter sp, Curtobacterium sp, Pseudomonas sp, Enterobacter sp, Bacillus spp, and Methylobacterium mesophilicum, whereas CVC-affected plants are preferential hosts of Methylobacterium spp. The genera Pseudomonas sp and Enterobacter sp were also isolated as endophytes from sugarcane (Magnani et al., 2013).

Two species of Microbacterium, namely, M. testaceum and M. paraoxydans, and the isolate Cellulomonas hominis were identified in endophytic isolates from M. emarginata. Within the eight genera identified from papaya tree, Thomas et al. (2007) reported the Enterobacter genus as usually isolated in endophyte conditions.

There are no reports in the literature on the genus Aureimonas isolated as endophytes, similar to that observed in the present study. Denner et al. (2003) were the first to describe the genus Aureimonas that, together with Fulvimarina and Martella, constitute the family Aurantimonadaceae within the order Rhizobiales (Kim et al., 2008). The genera described so far derive from corals, such as that originally reported by Denner et al. (2003) as Aurantimonas coralicida, from underground environments, Aurantimonas altamirensis (Jurado et al., 2006) and Aurantimonas ureilytica (Weon et al., 2007), and Aurantimonas frigidaquae (Kim et al., 2008) from cooling systems. Aurantimonas coralicida and Aurantimonas altamirensis were 
isolated from a diseased coral (Denner et al., 2003) and from underground soil (Jurado et al., 2006). In 2008, Kim et al. studied cooling water systems in South Korea and isolated a yellow bacterial strain identified as a new species of the genus Aurantimonas, called Aurantimonas frigidaquae. This is the first report of Aureimonas frigidaquae as a plant endophyte. However, based on the presence or absence of a glycolipid, the genus was re-classified by Rathsack et al. (2011). Those authors suggested that the genus Aurantimonas could be divided, and that the species Aurantimonas altamirensis, Aurantimonas ureilytica, and Aurantimonas frigidaquae could be transferred to a new genus named Aureimonas.

The taxonomic identification of Pseudomonas putida was confirmed in four isolates of M. emarginata. Endophytic bacteria of the genus Pseudomonas have already been isolated from several plant species, including Eucalyptus sp, sugar cane, and ginger (Procópio et al., 2009; Magnani et al., 2013; Chen et al., 2014). Kumar et al. (2014) isolated endophytic bacteria from Cassia tora roots and identified the species Pseudomonas putida among the isolates.

Consistent with the results of the present study, Barretti et al. (2009) isolated Acinetobacter johnsonii among endophytes from the tomato plant and showed this species to cause a significant decrease in the severity of the bacterial speck caused by Pseudomonas syringae. The genus Acinetobacter was also isolated as an endophyte in studies by Procópio et al. (2009).

Most of the isolated endophytes belong to the variety Olivier when the distribution of endophytes per variety of host species and isolation temperature are taken into account. The number of endophytes belonging to the genus Bacillus, identified in this variety, was similar (10) for each temperature evaluated $\left(28^{\circ}\right.$ and $\left.37^{\circ} \mathrm{C}\right)$. For the genera Staphylococcus, Cellulomonas, and Enterobacter, an equilibrium was reported between the number of isolates of the two varieties and the temperature. The number of endophytes belonging to Acinetobacter and Pseudomonas was greatest in the variety Olivier, whereas the variety Waldy Cati 30 only hosted isolates of the genera Micrococcus and Aureimonas.

In the current analysis, $92.30 \%$ of bacteria demonstrated antagonistic activity against phytopathogenic fungi. Furthermore, $12.82 \%$ inhibited the growth of all fungi analyzed, especially the endophyte G8O43 (A) (Bacillus sp), which had the highest inhibition index for four of the seven phytopathogens studied (Glomerella sp, F. solani, Alternaria sp, and F. oxysporum). However, $7.69 \%$ did not have any anti-fungus activity.

Tonelli et al. (2010) investigated endophytic and epiphytic bacteria isolated from Arachis hypogaea L. (peanut) and tested their anti-fungal potential against four main pathogens, namely, Sclerotinia sclerotiorum, S. menor, Sclerotium rolfsii, and Fusarium solani. The results showed that 19 endophytic isolates inhibited the growth of one or more fungi when analyzed on plates with yeast extract and mannitol agar (YEMI) medium, whereas nine isolates showed an antagonistic effect with PDA medium.

In their analysis of endophytic bacteria isolated from Theobroma cacao leaves, Melnick et al. (2011) reported that $30.7 \%$ of the 69 isolates tested for in vitro antagonistic activity inhibited the growth of Phytophthora capsici, 28.6\% inhibited Moniliophthora roreri, and $38.3 \%$ acted against $M$. perniciosa. The three pathogens were inhibited by $21.7 \%$ of isolates, with special reference to the species Bacillus amyloquefaciens, in which endophytic bacterial isolates of all species inhibited the growth of all pathogens. Similar results occurred for $80 \%$ of isolates from the species B. subtilis. Furthermore, Zhou et al. (2014) evaluated the antagonistic activity of Pseudomonas fluorescens against the fungus Athelia rolfsii and concluded that fungal growth was totally inhibited by endophytic bacteria. 
The results of the present study showed that $64.70 \%$ of the endophytic bacteria associated with $M$. emarginata produce at least one of the evaluated enzymes. The isolate G2O26 (B) (Bacillus thuringiensis) generated positive results for all enzymes under analysis and should be highlighted. The endophytic bacterium G3O2 (B) (Bacillus thuringiensis) also provided a good result in terms of enzyme production, except in the production of esterase. Although several isolates had EIs of over 2.0,32.45\% of the 34 endophytic bacterial isolates did not possess enzymatic activity. It should also be highlighted that the isolates G1O47 (B) (Staphylococcus sp) and G2O39 (A) (Staphylococcus sp) produced proteases with higher proteolytic activity than the commercial enzyme employed, highlighting the biotechnological potential of these isolates for industries (e.g., food and leather).

According to Sivaramakrishnan et al. (2006), bacteria of the genus Bacillus are used widely in the production of thermostable $\alpha$-amylase, which complies with industrial demands. B. subtilis, B. stearothermophilus, B. licheniformis, and B. amyloliquefaciens produce the highest amounts of this enzyme for commercial purposes and for several other applications.

Rodarte et al. (2011) assessed the capacity of microorganisms isolated from Coffea arabica L. grains to secrete extracellular proteases. Forty bacterial isolates were identified among the samples analyzed, of which $52.5 \%$ possessed enzymatic activity. In the present study, enzyme production in media containing hydrolyzed casein was divided into four levels, according to the diameter $(\mathrm{cm})$ of the degradation halo as follows: (-) no degradation; $(+)$ halos ranging between 0.1 and $0.5 \mathrm{~cm} ;(++)$ halos ranging between 0.5 and $0.8 \mathrm{~cm}$; and $(+++)$ for halos ranging between 0.8 and $1.0 \mathrm{~cm}$. The isolates Acinetobacter sp, Bacillus subtilis, Bacillus megaterium, Enterobacter agglomerans, Kurthia sp, Serratia plymutica, and Tatumella ptyseos possessed the highest enzyme activity.

Castro et al. (2014) studied two species of mangrove plants, Rhizophora mangle and Avicennia nitida, and semi-quantitatively evaluated the production of amylase, esterase, lipase, cellulase, and protease from 40 endophyte bacteria. Those authors reported that $75 \%$ of bacterial isolates possessed proteolytic activity, followed by $52.5 \%$ with lipolytic activity; $45 \%$ of the bacterial isolates revealed amylolytic activity, especially for the isolate MBA2.19 Erwinia sp with $\mathrm{EI}=6.83$ for lipase activity. In the case of protease, the group with the highest number of enzyme-producing isolates and the best index was MBA2.29 Stenotrophomonas $\mathrm{sp}(\mathrm{EI}=2.53)$.

The findings of this study demonstrated that $M$. emarginata is colonized by several different species of endophytic bacteria, and nine different genera are represented within the 58 identified. The genus Aureimonas, represented by the species Aureimonas frigidaquae, is highlighted for the first time in specialized literature as an endophytic isolate. Regarding the biotechnological potential, these results show that endophytic bacteria associated with acerola are capable of inhibiting the growth of $S$. sclerotiorum (a fungus highly difficult to control by in vitro microorganisms) and F. oxysporum (fusariosis-causing pathogen in acerola). The endophytes G1O47 (B) Staphylococcus sp and G2O39 (A) Staphylococcus sp produced proteases with statistically higher activity than those obtained commercially, which increases the interest in these endophytic bacteria, due to the fact that enzyme production by microorganisms is highly profitable, reinforcing the importance of prospecting enzymes of industrial interest associated to acerola.

\section{Conflicts of interest}

The authors declare no conflict of interest. 


\section{ACKNOWLEDGMENTS}

We thank CNPq (\#311534/2014-7; \#447265/2014-8) and Fundação Araucária - FA (\#276/2014) for financial support and Coordenação de Aperfeiçoamento de Pessoal de Nível Superior (CAPES) by the PNPD-UEM postdoctoral scholarship.

\section{REFERENCES}

Anand D, Padmanabhan SA, Deventhiran M and Saravanan P (2014). Isolation of Pseudomonas sp from Wrightia tinctoria leaf and its 16s rRna study. Ind. J. Sci. Res. 9: 28-31.

Arnold AE and Herre EA (2003). Canopy cover and leaf age affect colonization by tropical fungal endophytes: Ecological pattern and process in Theobroma cacao (Malvaceae). Mycologia 95: 388-398. http://dx.doi.org/10.2307/3761880

Azevedo JL, Maccheroni WJ, Pereira JO and Araujo WJ (2000). Endophytic microorganisms: a review on insect control and recent advances on tropical plants. Electron. J. Biotechnol. 3: 40-65. http://dx.doi.org/10.2225/vol3-issue1fulltext-4

Barretti PB, Romeiro RS, Mizubuti ESG and Souza JT (2009). Seleção de bactérias endofíticas de tomateiro como potenciais agentes de biocontrole e de promoção de crescimento. Cienc. Agrotec. 33: 2038-2044. http://dx.doi. org/10.1590/S1413-70542009000700057

Carrington CMS and King RAG (2002). Fruit development and ripening in Barbados cherry, Malpighia emarginata DC. Sci. Hortic. (Amsterdam) 92: 1-7. http://dx.doi.org/10.1016/S0304-4238(01)00268-0

Castro RA, Quecine MC, Lacava PT, Batista BD, et al. (2014). Isolation and enzyme bioprospection of endophytic bacteria associated with plants of Brazilian mangrove ecosystem. Springerplus 3: 382. http://dx.doi.org/10.1186/2193-1801$\underline{3-382}$

Cavichioli JC, Garcia MJM, Brida AL and Wilcken SRS (2014). Reaction in Barbados Cherry (Malpighia emarginata D.C.) to Meloidogyne enterolobii. Rev. Bras. Frutic. 36: 156-160. http://dx.doi.org/10.1590/0100-2945-429/13

Chebotar VK, Malfanova NV, Shcherbakov AV, Ahtemova GA, et al. (2015). Endophytic Bacteria in Microbial Preparations that Improve Plant Development. Prikl. Biokhim. Mikrobiol. 51: 271-277. http://dx.doi.org/10.7868/ $\underline{\text { S0555109915030058 }}$

Chen T, Chen Z, Ma GH, Du BH, et al. (2014). Diversity and potential application of endophytic bacteria in ginger. Genet. Mol. Res. 13: 4918-4931. http://dx.doi.org/10.4238/2014.July.4.6

Denner EBM, Smith GW, Busse H-J, Schumann P, et al. (2003). Aurantimonas coralicida gen. nov., sp. nov., the causative agent of white plague type II on Caribbean scleractinian corals. Int. J. Syst. Evol. Microbiol. 53: 1115-1122. http:// dx.doi.org/10.1099/ijs.0.02359-0

Duza MB and Mastan SA (2013). Microbial enzymes and their applications - A Review. Indo American J. Pharmaceut. Res 3: 6208-6219.

Ferreira DF (2011). Sisvar: a computer statistical analysis system. Cienc. Agrotec. 35: 1039-1042.

Gujral MS, Agrawal P, Khetmalas MB and Pandey R (2013). Colonization and plant growth promotion of Sorghum seedlings by endorhizospheric Serratia sp. Acta Biol. Indica 2: 121-124.

Jurado V, Gonzalez JM, Laiz L and Saiz-Jimenez C (2006). Aurantimonas altamirensis sp. nov., a member of the order Rhizobiales isolated from Altamira Cave. Int. J. Syst. Evol. Microbiol. 56: 2583-2585. http://dx.doi.org/10.1099/ ijs.0.64397-0

Kim MS, Hoa KTQ, Baik KS, Park SC, et al. (2008). Aurantimonas frigidaquae sp. nov., isolated from a water-cooling system. Int. J. Syst. Evol. Microbiol. 58: 1142-1146. http://dx.doi.org/10.1099/ijs.0.65421-0

Kumar V, Kumar A, Pandey KD and Roy BK (2014). Isolation and characterization of bacterial endophytes from the roots of Cassia tora L. Ann. Microbiol. 65: 1391-1399. http://dx.doi.org/10.1007/s13213-014-0977-x

Kusari S, Hertweck C and Spiteller M (2012). Chemical ecology of endophytic fungi: origins of secondary metabolites. Chem. Biol. 19: 792-798. http://dx.doi.org/10.1016/j.chembiol.2012.06.004

Lacava PT and Azevedo JL (2013). Endophytic bacteria: A biotechnological potential in agrobiology system. In: Bacteria in Agrobiology: Crop Productivity (Maheshwari, DK, Saraf M and Aeron A, eds.). Springer, Berlin, Heidelberg, 1-44.

Lacava PT, Andreote FD, Araújo WL and Azevedo JL (2006). Caracterização da comunidade bacteriana endofítica de citros por isolamento, PCR específico e DGGE. Pesquisa Agropecu. Bras. 41: 637-642. http://dx.doi.org/10.1590/ $\underline{\text { S0100-204X2006000400013 }}$

Magnani GS, Cruz LM, Weber H, Bespalhok JC, et al. (2013). Culture-independent analysis of endophytic bacterial 
communities associated with Brazilian sugarcane. Genet. Mol. Res. 12: 4549-4558. http://dx.doi.org/10.4238/2013. October. 15.3

Melnick RL, Suárez C, Bailey BA and Backman PA (2011). Isolation of endophytic endospore-forming bacteria from Theobroma cacao as potential biological control agents of cacao diseases. Biol. Control 57: 236-245. http://dx.doi. org/10.1016/j.biocontrol.2011.03.005

Nogueira CAM, Momesso CAS, Machado RLD, Almeida MTG, et al. (2004). Desempenho de Kits comerciais e protocolos laboratoriais para a extração de DNA genômico bacteriano. Rev. Panam. Infectol. 6: 35-38.

Oliveira NA, Oliveira LA, Andrade JS and Chagas Júnior AF (2006). Atividade enzimática de isolados de rizóbia nativos da Amazônia central crescendo em diferentes níveis de acidez. Ciênc. Tecnol. Aliment. 26: 204-210. http://dx.doi. org/10.1590/S0101-20612006000100032

Procópio REL, Araújo WL, Maccheroni W, Jr. and Azevedo JL (2009). Characterization of an endophytic bacterial community associated with Eucalyptus spp. Genet. Mol. Res. 8: 1408-1422. http://dx.doi.org/10.4238/vol8-4gmr691

Rathsack K, Reitner J, Stackebrandt E and Tindall BJ (2011). Reclassification of Aurantimonas altamirensis (Jurado et al. 2006), Aurantimonas ureilytica (Weon et al. 2007) and Aurantimonas frigidaquae (Kim et al. 2008) as members of a new genus, Aureimonas gen. nov., as Aureimonas altamirensis gen. nov., comb. nov., Aureimonas ureilytica comb. nov. and Aureimonas frigidaquae comb. nov., and emended descriptions of the genera Aurantimonas and Fulvimarina. Int. J. Syst. Evol. Microbiol. 61: 2722-2728. http://dx.doi.org/10.1099/ijs.0.027029-0

Rodarte MP, Dias DR, Vilela DM and Schwan RF (2011). Proteolytic activities of bacteria, yeasts and filamentous fungi isolated from coffee fruit (Coffea arabica L.). Acta Sci. Agron. 33: 457-464.

Santos SML, De Vasconcelos AM, Oliveira VO, Clemente E, et al. (2012). Evaluation of Physical and Physicochemical Characteristics of Malpighia emarginata DC from the State of Ceará. Int. J. Biochem. Res. Rev 2: 152-163. http:// dx.doi.org/10.9734/IJBCRR/2012/1945

Schlaberg R, Simmon KE and Fisher MA (2012). A systematic approach for discovering novel, clinically relevant bacteria. Emerg. Infect. Dis. 18: 422-430. http://dx.doi.org/10.3201/eid1803.111481

Seo WT, Lim WJ, Kim EJ, Yun HD, et al. (2010). Endophytic bacterial diversity in the young radish and their antimicrobial activity against pathogens. J. Korean Soc. Appl. Bi. 53: 493-503. http://dx.doi.org/10.3839/jksabc.2010.075

Sessitsch A, Reiter B and Berg G (2004). Endophytic bacterial communities of field-grown potato plants and their plantgrowth-promoting and antagonistic abilities. Can. J. Microbiol. 50: 239-249. http://dx.doi.org/10.1139/w03-118

Sivaramakrishnan S, Gangadharan D, Nampoothiri KM, Soccol CR, et al. (2006). $\alpha$-Amylases from microbial sources - an overview on recent developments. Food Technol. Biotechnol. 44: 173-184.

Soria S, Alonso R and Bettucci L (2012). Endophytic bacteria from Pinus taeda L. as biocontrol agents of Fusarium circinatum Nirenberg \& O'Donnell. Chil. J. Agric. Res. 72: 281-284. http://dx.doi.org/10.4067/S0718$\underline{58392012000200018}$

Souza A, Cruz JC, Sousa NR, Procópio ARL, et al. (2014). Endophytic bacteria from banana cultivars and their antifungal activity. Genet. Mol. Res. 13: 8661-8670. http://dx.doi.org/10.4238/2014.October.27.6

Tamura K, Stecher G, Peterson D, Filipski A, et al. (2013). MEGA6: Molecular Evolutionary Genetics Analysis version 6.0. Mol. Biol. Evol. 30: 2725-2729. http://dx.doi.org/10.1093/molbev/mst197

Teixeira MA, Melo IS, Vieira RF, Costa FEC, et al. (2007). Microrganismos endofíticos de mandioca de áreas comerciais e etnovariedades em três estados brasileiros. Pesquisa Agropecu. Bras. 42: 43-49. http://dx.doi.org/10.1590/S0100204X2007000100006

Thomas P, Kumari S, Swarna GK and Gowda TKS (2007). Papaya shoot tip associated endophytic bacteria isolated from in vitro cultures and host-endophyte interaction in vitro and in vivo. Can. J. Microbiol. 53: 380-390. http://dx.doi. org/10.1139/W06-141

Tonelli ML, Taurian T, Ibáñez F, Angelini J, et al. (2010). Selection and in vitro characterization of biocontrol agents with potential to protect peanut plants against fungal pathogens. J. Plant Pathol. 92: 73-82.

Weon HY, Kim BY, Yoo SH, Joa JH, et al. (2007). Aurantimonas ureilytica sp. nov., isolated from an air sample. Int. J. Syst. Evol. Microbiol. 57: 1717-1720. http://dx.doi.org/10.1099/ijs.0.65035-0

West ER, Cother EJ, Steel CC and Ash GJ (2010). The characterization and diversity of bacterial endophytes of grapevine. Can. J. Microbiol. 56: 209-216. http://dx.doi.org/10.1139/W10-004

Zhou JY, Zhao XY and Dai CC (2014). Antagonistic mechanisms of endophytic Pseudomonas fluorescens against Athelia rolfsii. J. Appl. Microbiol. 117: 1144-1158. http://dx.doi.org/10.1111/jam.12586 